\title{
TONO Y ACENTO EN EL PIDGIN AFROPORTUGUÉS AMERICANO
}

\author{
Mario Portilla
}

\begin{abstract}
RESUMEN
El presente artículo presenta la reconstrucción de los supragementales de un pidgin afroportugués utilizado en América durante el siglo XVII mediante la aplicación del Método Comparativo. Esta protolengua dio origen al saramaca (Surinam), papiamento (islas ABC) y palenquero (Colombia). Palabras clave: Lenguas criollas, pidgin portugués, reconstrucción fonológica, saramaca, papiamento, palenquero.
\end{abstract}

\begin{abstract}
This article provides the suprasegmental reconstruction of an Afro-Portuguese pidgin spoken in the Americas in the XVII Century using the principles of the Historical Comparative Method. This proto-languages gave rise to Saramaccan (Surinam), Papiamentu (ABC islands), and Palenquero (Colombia).

Key words: Creole languages, Portuguese pidgin, phonological reconstruction, Saramaccan, Papiamentu, Palenquero.
\end{abstract}

\section{Introducción}

Existen suficientes datos históricos (cf. Bartens 1995, Bakker et al. 1995, Kouwenberg \& Muysken 1995, Schwegler 1999 y Patiño 2002) que permiten suponer que el papiamento (Antillas Holandesas), el saramaca (Surinam) y el palenquero (Colombia) provienen de un mismo pidgin de origen portugués utilizado en América entre mediados del siglo XVII y principios del siglo XVIII. Portilla (2008a) ha mostrado que estas variedades poseen un vocabulario común (unos 27 rubros), el cual presenta particularidades que solo comparten

Dr. Mario Portilla. Profesor Catedrático de la Universidad de Costa Rica. San José, Costa Rica. Correo electrónico: marioportilla2000@yahoo.com

Recepción: 28- 02- 2010

Aceptación: 27- 03- 2010 * 
estas lenguas y que no aparecen ni en el portugués estándar ni en el español. Este hecho constituye un indicio lingüístico muy fuerte del origen compartido de estos criollos.

Luego de haber establecido la relación genealógica de estas variedades, Portilla (2007) y (2008b) lleva a cabo la reconstrucción completa del sistema segmental (vocales y consonantes) del protopidgin afroportugués que habría dado origen al papiamento, saramaca y palenquero.

El presente trabajo tiene el propósito de realizar la reconstrucción de los suprasegmentales de esta variedad prototípica mediante la aplicación del Método Comparativo. Para la comparación, se ha utilizado una lista de 117 grupos de cognados, los cuales fueron establecidos para la reconstrucción del sistema de segmentos vocálicos y consonánticos mencionada anteriormente. Estos grupos de cognados fueron establecidos con base en las siguientes fuentes primarias: Para el saramaca, los datos son de Huttar (1972), el Saramaccan-English Dictionary del SIL (Summer Institute of Linguistics) y Taylor (1977); para el papiamento son de Maurer (1998b), Maduro (1987), el Papiamento-English/ EnglishPapiamento lexicon y el Amaro's papiamentu Project; y para el palenquero son de Maduro (1987), Cásseres (2005), Megenny (1986) y Friedemann \& Patiño (1983).

\section{Los suprasegmentales en las variedades comparadas}

\subsection{El papiamento}

Esta lengua presenta los siguientes suprasegmentales: acento dinámico (marcado con una comilla superpuesta) y dos tonos, uno alto (marcado con una tilde) y uno bajo (sin señalar gráficamente). Tanto el acento como el tono tienen una función contrastiva en la lengua. La aparición de los tonos en la palabra presenta restricciones. En palabras polisilábicas, solamente puede aparecer un tono alto y no existen palabras polisilábicas que contengan solamente tonos bajos. Estas restricciones son típicas de las llamadas lenguas de acento tonal (pitch accent languages).

\subsubsection{Acento}

Desde el punto de vista fonético, el correlato primario del acento en papiamento parece ser la duración de la sílaba. La sílaba con acento primario es más larga que las sílabas inacentuadas. En general, las sílabas acentuadas son el doble de largas que las sílabas inacentuadas (Rivera-Castillo \& Pickering 2004: 278).

Además, las sílabas finales de enunciado tienden a ser más largas que las sílabas no finales, independientemente de que estén acentuadas o no. Sin embargo, las sílabas acentuadas que también tienen una vocal con tono alto son más largas que las sílabas acentuadas con vocales con tono bajo. Véase la duración de las sílabas de las palabras pis'ká pescado (sílaba inacentuada+tono bajo - sílaba acentuada+tono alto) y (piská pescar (sílaba acentuada+tono bajo - sílaba inacentuada+tono alto) en los siguientes ejemplos (adaptado de Rivera-Castillo \& Pickering 2004: 279):

\section{Duración silábica en milisegundos}

mi 'ké pis'ká Quiero pescado mi 'ké 'piská Quiero pescar

$$
\begin{array}{ll}
\text { pis }=48 \mathrm{~ms} . & \mathrm{ka}=118 \mathrm{~ms} . \\
\text { pis }=95 \mathrm{~ms} . & \mathrm{ka}=114 \mathrm{~ms} .
\end{array}
$$


Por último, según el estudio de Rivera-Castillo \& Pickering (2004: 279), en promedio las penúltimas sílabas acentuadas y con tono alto son más largas (127 ms) que las últimas sílabas también acentuadas y con tono alto (113 ms).

Desde el punto de vista fonológico, en papiamento, solamente una sílaba es portadora de un acento primario. Existen dos patrones principales en la asignación del acento en papiamento en palabras polisilábicas. La tendencia más general es que el acento recaiga en la penúltima sílaba (Rivera-Castillo \& Pickering 2004: 264), especialmente cuando la palabra termina en una vocal o en las sonantes / r, 1, n /, sobre todo cuando van precedidas de la vocal / e /, realizada fonéticamente como una vocal central media [ ə ] (ortográficamente $-e r,-e l,-e n$ ) (Kouwenberg \& Muysken 1995), por ejemplo, en las siguientes palabras:

$\begin{array}{ll}\text { 'píska } & \text { pesca } \\ \text { 'piská } & \text { pescar } \\ \text { 'máta } & \text { planta } \\ \text { 'matá } & \text { matar } \\ \text { ku'mínda } & \text { comida } \\ \text { 'líber } & \text { libre } \\ \text { 'ápel } & \text { manzana } \\ \text { 'hóben } & \text { joven }\end{array}$

Por otro lado, por lo general, las palabras polisilábicas que terminan en cualquier consonante (incluidas las sonantes / r, l, n /) llevan el acento en la última sílaba:

$\begin{array}{ll}\text { kura'són } & \begin{array}{l}\text { corazón } \\ \text { doce }\end{array} \\ \text { dies'dós } & \text { virtud } \\ \text { bir'tút } & \text { animal } \\ \text { ani'mál } & \text { barraca } \\ \text { ba'rák } & \text { poder } \\ \text { po'dér } & \end{array}$

En estos casos, la sílaba acentuada siempre corresponde al lugar de asignación del tono alto. Aunque estos son los patrones generales de asignación del acento en papiamento, existen tres excepciones principales. El primer grupo de excepciones está constituido por una cantidad reducida de palabras polisilábicas terminadas en vocal, en las cuales el acento recae en la antepenúltima sílaba:

$\begin{array}{ll}\text { 'último } & \text { último } \\ \text { pe'nínsula } & \text { península } \\ \text { sien'tífiko } & \text { científico } \\ \text { 'sílaba } & \text { sílaba }\end{array}$

Es evidente que se trata sobre todo de palabras de origen español tomadas en préstamo.

El segundo grupo se trata de verbos trisilábicos o tetrasilábicos terminados en vocal que llevan el acento en la última sílaba:

$\begin{array}{ll}\text { kumin'sá } & \text { comenzar } \\ \text { ekibo'ká } & \text { equivocar } \\ \text { bando'ná } & \text { abandonar } \\ \text { dete'né } & \text { detener }\end{array}$


El tercer grupo está constituido por sustantivos y participios bisilábicos terminados en vocal que portan el acento en la última sílaba:

$\begin{array}{ll}\text { mu'hé } & \text { mujer } \\ \text { do'ló } & \text { dolor } \\ \text { pis'ká } & \text { pez, pescado } \\ \text { ma'tá } & \text { matado } \\ \text { sol'dá } & \text { soldado }\end{array}$

En estos casos, también el lugar de asignación del acento corresponde al lugar ocupado por el tono alto en la palabra.

Por último, se debe mencionar que, en palabras trisilábicas y tetrasilábicas, aparece un acento secundario (marcado con una comilla infrapuesta) asignado cada dos sílabas a la izquierda de la sílaba que porta el acento primario. Este acento secundario no tiene valor contrastivo (cf. ejemplos en Rivera-Castillo \& Pickering 2004: 264 y Maurer 1998a: 33)

$\begin{array}{ll}\text { kumin'sa [,kumin'sá] } & \text { comenzar } \\ \text { awa'séru [,awa'séru] } & \text { aguacero } \\ \text { awa'sá [,awa'sá] } & \text { Awasá (topónimo) } \\ \text { anta'jéra [,anta'jera] } & \text { anteayer }\end{array}$

\subsubsection{Tono}

Fonéticamente, el tono en papiamento se expresa por medio de altura tonal (pitch height). El correlato fonético de la altura tonal es la amplitud de la frecuencia fundamental (F0) de las vocales expresada en hercios (Hz). La frecuencia fundamental es más alta en las vocales que presentan un tono alto que en aquellas que tienen un tono bajo. En algunos casos, el promedio de la diferencia entre la F0 de las vocales con tono alto (v.gr. $234 \mathrm{~Hz}$ ) y la F0 de aquellas con tono bajo (v.gr. $200 \mathrm{~Hz}$ ) es de hasta $37.6 \mathrm{~Hz}$ en un mismo enunciado (Rivera-Castillo \& Pickering 2004: 272-273).

Fonológicamente, el papiamento presenta dos tonos de nivel, uno alto y uno bajo. En palabras polisilábicas, existe la restricción de que solamente puede aparecer un tono alto por palabra. Como se ha dicho, en gran parte de los casos, el lugar que ocupa un tono en la palabra se corresponde con la asignación del acento en la sílaba de esa palabra.

Existe, sin embargo, una serie de excepciones a esta correspondencia que muestran que el tono tiene carácter distintivo en esta lengua. El primer grupo de excepciones está compuesto por verbos bisilábicos. En esta clase de palabras, el acento recae en la primera sílaba de la palabra y el tono alto aparece en la vocal de la última sílaba.

Este patrón de asignación tonal BA para las formas básicas de los verbos bisilábicos se opone al patrón de tonos $\mathrm{AB}$, que corresponde a los sustantivos.

Verbos (tonos BA)

$\begin{array}{ll}\text { 'piská } & \text { pescar } \\ \text { 'máta } & \text { matar } \\ \text { 'biahá } & \text { viajar }\end{array}$

Sustantivos (tonos $A B$ )

$\begin{array}{ll}\text { 'píska } & \text { pesca } \\ \text { máta } & \text { planta } \\ \text { 'biáha } & \text { viaje }\end{array}$




$\begin{array}{llll}\text { 'burlá } & \text { burlar } & \text { 'búrla } & \text { burla } \\ \text { 'yuná } & \text { ayunar } & \text { 'yúna } & \text { ayuno } \\ \text { 'ará } & \text { arar } & \text { 'ára } & \text { arado }\end{array}$

Ha sido reportada una lista de más de 250 pares de palabras (verbos vs. sustantivos) (pares mínimos) que se oponen por los patrones de asignación de los tonos mencionados anteriormente (cf. Kramer 2004: 160, Kouwenberg \& Muysken 1994: 208).

El segundo grupo de excepciones está formado por un pequeño número de sustantivos, pronombres y adverbios, que también presenta el patrón de asignación tonal BA (Maurer 1998a: 14).

$\begin{array}{ll}\text { Tonos BA } & \\ \text { 'djaká } & \text { rata } \\ \text { 'mutJá } & \text { muchacho } \\ \text { 'hosé } & \text { José (antropónimo) } \\ \text { 'bosó } & \text { ustedes } \\ \text { 'amí } & \text { yo (enfático) } \\ \text { 'akí } & \text { aquí } \\ \text { 'awé } & \text { hoy } \\ \text { 'també } & \text { también } \\ \text { 'trobé } & \text { otra vez }\end{array}$

También, existe una pequeña cantidad de verbos en su forma básica que presentan el patrón de asignación tonal AB (Maurer 1998a: 147).

Tonos $A B$

$\begin{array}{ll}\text { 'sábi } & \text { saber } \\ \text { 'tíni } & \text { tener } \\ \text { 'fángu } & \text { coger }\end{array}$

De acuerdo con Kramer (2004: 160), se pueden reconocer los siguientes patrones de distribución tonal (AB) y acentual en verbos, los cuales están determinados por la función gramatical que desempeñan:

a. Verbos en forma básica

Patrón de suprasegmentales: Acento+tono bajo - tono alto.

Ejemplos: 'duná dar, 'piská pescar, 'matá matar.

\section{b. Verbos en forma imperativa}

Patrón de suprasegmentales: Acento+tono alto - tono bajo.

Ejemplos: 'dúna $d a$, 'píska pescá, 'máta matá.

c. Verbos en forma participial (o un sustantivo derivado de ella)

Patrón de suprasegmentales: Tono bajo - acento+tono alto.

Ejemplos: du'ná dado, pis'ká pescado, pez, ma'tá matado. 
Además, hay que agregar que las palabras monosilábicas pueden portar o bien un tono alto o bien un tono bajo. Incluso, pueden encontrarse pares mínimos distinguidos solamente por el tono:

$\begin{array}{ll}\text { é } & \text { Artículo definido } \\ \text { e } & \text { Pronombre } 3 p \text { singular } \\ \text { tá } & \text { Tiempo presente } \\ \text { na } & \text { Preposición locativa }\end{array}$

Debido a las restricciones en la asignación de los tonos mencionadas anteriormente, se puede afirmar que el papiamento es una lengua de acento tonal (cf. Hyman 1978). Como es normal en este tipo de lenguas, el sistema tonal del papiamento presenta los siguientes fenómenos típicos de las lenguas tonales: asimilación tonal (spreading), polarización, tonos de registro (contour tones), conservación tonal, tonos flotantes y descenso tonal (downdrift) (cf. Rivera-Castillo \& Pickering 2004: 264-265).

Por razones comparativas, se menciona a continuación la regla de asimilación tonal. Según los datos de Rivera-Castillo \& Pickering (2004: 264-265), esta consiste en que un tono fonológicamente bajo de una vocal se convierte en un tono fonéticamente alto después de una vocal con tono alto de una sílaba adyacente:

$$
\begin{array}{lll}
\text { é sáku á skér } & \Rightarrow & \text { [é sákú á skér] } \\
/ \mathrm{A}+\mathbf{A B}+\mathrm{A}+\mathrm{A} / & \Rightarrow & {[\mathrm{A}+\mathbf{A} \mathbf{A}+\mathrm{A}+\mathrm{A}]} \\
\text { La bolsa se rompió } &
\end{array}
$$

\subsection{El saramaca}

Voorhoeve (1961) y Rountree (1972a) describen al saramaca como una lengua tonal. Good (2004a) ha mostrado, sin embargo, que el saramaca presenta un sistema prosódico de dos tipos: de acento tonal (pitch accent) y de tono (tone). Por ello, según él, el léxico de esta lengua está dividido en dos clases. La mayor parte de las palabras polisilábicas presenta un solo tono alto, lo cual es propio de las lenguas de acento tonal. Pero, existe una significativa minoría del vocabulario que es portador de tonos subyacentes, altos y bajos, los cuales están asignados léxicamente a cada una de las vocales de la palabra, como sucede habitualmente en las llamadas lenguas tonales.

La división del léxico en esta lengua en dos sistemas prosódicos parece deberse fundamentalmente al origen del vocabulario. Así, las palabras de lenguas indoeuropeas, del portugués, inglés y holandés, presentan, por lo general, un acento tonal (expresado fonéticamente como un tono alto); mientras que las palabras con tonos subyacentes provienen de lenguas africanas, especialmente del kikongo y del fon ${ }^{1}$ (Good 2009b), que pertenecen a la familia niger-congo.

Además, el saramaca presenta también un acento de intensidad (stress), el cual es predecible por el lugar que ocupa el acento tonal.

\subsubsection{Acento tonal y tono}

Fonéticamente, tanto el acento tonal como un tono alto subyacente se manifiestan por medio de la misma altura tonal. Esto quiere decir que, desde el punto de vista acústico, 
no existe ninguna diferencia de amplitud en la frecuencia fundamental (F0) entre una vocal con un tono alto de una palabra con acento tonal y una vocal con un tono alto de una palabra portadora de tonos altos subyacentes. Tampoco un tono bajo asignado a una vocal inacentuada se distingue en altura de un tono bajo subyacente (Good 2006).

De manera consistente, un tono fonéticamente alto presenta una amplitud mayor de la F0 en la vocal que un tono fonéticamente bajo. En palabras que no son ideófonos, la altura tonal de las vocales con tonos altos alcanza un promedio de $127-131 \mathrm{~Hz}$, mientras que aquella de las vocales con tonos bajos llega a un promedio de 104-106 Hz (Good 2006: 20, Tabla 8).

Fonológicamente, el acento tonal tiene un carácter contrastivo en esta lengua. Como se ha dicho, el acento tonal aparece especialmente en palabras de origen portugués, inglés y holandés. El lugar que ocupa el tono alto (que corresponde al acento tonal) en palabras polisilábicas no es predecible. En palabras primitivas ${ }^{2}$ de origen europeo, la aparición de tonos altos (que expresan el acento tonal) está restringida a los siguientes patrones de distribución ( $\mathrm{A}=$ tono alto [presencia de acento]; B = tono bajo [ausencia de acento]) (cf. Good 2009a, Tabla 3):

\section{Palabras bisilábicas}

Tonos $A B$

bái comprar, llamar (< ing. bay, ball)

ábi tener $(<$ ing. have)

dáka día $(<$ hol. dag)

Tonos BA

baí barrer (< port. barrer)

butá poner (< port. butar)

bebé beber (< port. beber)

\section{Palabras trisilábicas}

Tonos $A A B$

$\begin{array}{ll}\text { síkísi } & \text { seis }(<\text { ing. six }) \\ \text { túwénti } & \text { veinte }(<\text { ing. } \text { twenty }) \\ \text { sákísi } & \text { serrín }(<\text { hol. zaagsel }) \\ \text { mákíti } & \text { poder }(<\text { hol. macht }) \\ \text { wólúku } & \text { nube }(<\text { hol. wolk) } \\ \text { dzákíti } & \text { chaqueta }(<\text { ing. jacket }) \\ \text { túmúsi } & \text { bastante }(<\text { ing. too much }) \\ \text { fósíten } & \text { antes }(<\text { ing. first time }) \\ \text { Tonos BAB } & \\ \text { maáka } & \text { marca }(<\text { port. marca }) \\ \text { miníti } & \text { minuto }(<\text { ing. minute }) \\ \text { sikáda } & \text { escalera }(<\text { port. escada }) \\ \text { Tonos BBA } & \\ \text { maaká } & \text { marcar }(<\text { port. marcar }) \\ \text { miindzá } & \text { orinar }(<\text { port. mijar }) \\ \text { amaján } & \text { mañana }(<\text { port. amanhã })\end{array}$




\section{Palabras tetrasilábicas}

Tonos $B B A B$

\begin{tabular}{|c|c|}
\hline $\begin{array}{l}\text { sukuáti } \\
\text { paamúsi } \\
\text { bangulútu }\end{array}$ & $\begin{array}{l}\text { chocolate }(<\text { port. chocolate }) \\
\text { prometer }(<\text { port. promise }) \\
\text { bancarrota }(<\text { hol. bankroet })\end{array}$ \\
\hline Tonos BAAB & \\
\hline $\begin{array}{l}\text { tuwálúfu } \\
\text { minísíti }\end{array}$ & $\begin{array}{l}\text { doce }(<\text { ing. twelve }) \\
\text { ministro }(<\text { hol. minister })\end{array}$ \\
\hline $\begin{array}{l}\text { Tonos } B B B A^{3} \\
\text { ameckán } \\
\text { afiikán }\end{array}$ & $\begin{array}{l}\text { americano }(<\text { hol. Amerikaan }) \\
\text { africano }(<\text { hol. Afrikaan })\end{array}$ \\
\hline
\end{tabular}

Por otro lado, las palabras con tonos subyacentes provienen, por lo general, de lenguas de la familia niger-congo. Como es típico en las lenguas tonales, no existen restricciones en la aparición de los tonos altos y bajos por palabra, ya que estos son asignados léxicamente a estas. Según Good (2004a, Tabla 4) se pueden encontrar los siguientes patrones de asignación de tonos altos y tonos bajos subyacentes (marcado con la tilde de acento grave) en el léxico del saramaca.

\section{Palabras solo con tonos altos}

$\begin{array}{lll}\text { Tono } A & \text { tú } & \text { dos }(<\text { ing. two }) \\ \text { Tonos } A A & \text { kódó } & \text { continuamente, siempre } \\ \text { Tonos } A A A & \text { búúu } & \text { ideófono de completamente }\end{array}$

\section{Palabras solo con tonos bajos}

$\begin{array}{lll}\text { Tono } B & \text { bà } & \text { llevar (agua) } \\ \text { Tonos BB } & \text { bòsò } & \text { aflojar } \\ \text { Tonos BBB } & \text { lègèdè } & \text { chisme, mentira }\end{array}$

\section{Palabras con tonos altos y bajos combinados}

$\begin{array}{lll}\text { Tonos } B A & \text { àkí } & \text { aquí (< port. aquí) } \\ \text { Tonos } A B B & \text { káìmà } & \text { lagarto } \\ \text { Tonos } A A B A & \text { tótómbòtí } & \text { pájaro carpintero } \\ \text { Tonos } A A B B A & \text { sćségùgùsé } & \text { clase de pájaro }\end{array}$

Como se nota en los ejemplos de Good (2004a) ofrecidos anteriormente, las palabras monosilábicas presentan o bien un tono alto o bien un tono bajo. Al parecer, el origen del vocabulario no es obstáculo para asignar tonos altos o tonos bajos subyacentes a las palabras monosilábicas. Así, incluso se pueden encontrar parejas mínimas de palabras que se distinguen solamente por la naturaleza del tono.

\section{Palabras monosilábicas con tono alto}

mí pronombre 1p. sing. enfático (< port. mim)

kú vagina 
tú $\quad \operatorname{dos}(<$ ing. two $)$

má pronombre lp. sing. negativo $(<\mathrm{mi}+$ ná)

\section{Palabras monosilábicas con tono bajo}

mì pronombre lp. sing. no enfático (< port. mim)

kù $\quad y, c o n$ (port. com)

tù también $(<$ ing. too $)$

mà pero $(<$ port. mas $)$

La distinción entre los tonos altos y los tonos bajos que corresponden a la presencia o ausencia de acento en la sílaba y los tonos altos y tonos bajos subyacentes asignados léxicamente se pone de manifiesto por ciertas restricciones en la aplicación de una regla sandhi o de asimilación tonal que es general en saramaca. Estas restricciones son descritas pormenorizadamente tanto en Rountree (1972) como en Good (2004a, 2004b y 2006). ${ }^{4}$ Esta regla consiste en que los tonos bajos que siguen a tonos altos, en ciertas condiciones gramaticales, se convierten en tonos altos. Esta regla se aplica solamente cuando los tonos bajos corresponden a la ausencia de acento tonal $\left(\mathrm{B}^{0}\right)$. Si se trata de tonos bajos subyacentes $\left(\mathrm{B}^{\mathrm{s}}\right)$, entonces la regla es bloqueada. La aplicación de esta regla puede verse en los siguientes ejemplos (Rountree 1972a):

(1) dí sukuáti súti

$$
\begin{array}{ll}
\Rightarrow & {[\text { dí súkúátí súti }]} \\
\Rightarrow & {[\mathrm{A}+\mathrm{AAAA}+\mathrm{AB}]}
\end{array}
$$

$/ \mathrm{A}+\mathrm{B}^{0} \mathrm{~B}^{0} \mathrm{AB}^{0}+\mathrm{AB}^{0} /$

\section{El chololate está bueno}

$$
\begin{array}{lll}
\text { dí dési tá kulá sèmbè } & \Rightarrow & {[\text { dí déésí tá kúlá sembe] }} \\
/ \mathrm{A}+\mathrm{B}^{0} \mathrm{AB} \mathrm{B}^{0}+\mathrm{A}+\mathrm{B}^{0} \mathrm{~A}+\mathrm{B}^{\mathrm{s}} \mathrm{B}^{\mathrm{s} /}=> & {[\mathrm{A}+\mathrm{AAA}+\mathrm{A}+\mathrm{AA}+\mathrm{BB}]}
\end{array}
$$

La medicina cura a la gente.

$$
\begin{array}{lll}
\text { dí wómi kulé dé } & \Rightarrow & {[\text { dí wómí kúlé de] }} \\
/ \mathrm{A}+\mathrm{AB}^{0}+\mathrm{B}^{0} \mathrm{~A}+\mathrm{A} / & \Rightarrow & {[\mathrm{A}+\mathrm{AA}+\mathrm{AA}+\mathrm{B}]}
\end{array}
$$

El hombre está corriendo allá

$$
\begin{array}{lll}
\text { dí káìmà kulé alá } & => & {[\text { dí káima kulé alā] }} \\
/ \mathrm{A}+\mathrm{AB}^{\mathrm{s}} \mathrm{B}^{\mathrm{s}}+\mathrm{B}^{0} \mathrm{~A}+\mathrm{B}^{\mathrm{s}} \mathrm{A} / & \Rightarrow & {[\mathrm{A}+\mathrm{ABB}+\mathrm{BA}+\mathrm{BM}]} \\
\text { El lagarto está corriendo allá. } &
\end{array}
$$

En los ejemplos anteriores, las palabras con tonos bajos subyacentes (sc̀mbè, káìmà, àlá) bloquean la regla de asimilación tonal, mientras que las palabras con tonos bajos que corresponden a ausencia de acento la permiten (sukuáti, dési, kulá, kulé).

Los ejemplos (3) y (4) también ilustran una regla de descenso final (downstep) de enunciado afirmativo que existe en saramaca (Rountree 1972a: 309). ${ }^{5}$ En esta lengua, por un lado, un tono (A) se realiza como un tono bajo (B) cuando va precedido de otro tono alto (A) (ejemplos 3 y 5). Por otro lado, un tono alto (A) se realiza como tono medio (M) cuando está precedido de un tono bajo (B) (ejemplos 4 y 6 ).

$$
\begin{array}{lll}
\text { a disá dí ló janán dé } & \Rightarrow & \text { [a disá dí ló nánán } \mathrm{d} \varepsilon] \\
/ \mathrm{B}^{0}+\mathrm{B}^{0} \mathrm{~A}+\mathrm{A}+\mathrm{A}+\mathrm{B}^{0} \mathrm{~A}+\mathrm{A} /=> & {[\mathrm{A}+\mathrm{BA}+\mathrm{A}+\mathrm{A}+\mathrm{AA}+\mathrm{B}]} \\
\text { Él dejo la comida ahí } &
\end{array}
$$


(6)

$$
\begin{array}{lll}
\text { dí hánso sćsćgùùsé } & \Rightarrow & {[\text { dí hánsó sésćguusē }]} \\
/ \mathrm{A}+\mathrm{AB}^{0}+\mathrm{AAB}^{\mathrm{s}} \mathrm{B}^{\mathrm{s}} \mathrm{A} / & \Rightarrow & {[\mathrm{A}+\mathrm{AA}+\mathrm{AABBM}]} \\
\text { El bonito pez sćsćgùùsé. } & &
\end{array}
$$

\subsubsection{Acento dinámico}

Rountree (1972a) señala que las sílabas con acento dinámico o de intensidad (stress) son más fuertes, ligeramente más largas y con los tonos ligeramente exagerados. ${ }^{6}$ Es decir, los correlatos fonéticos del acento dinámico en saramaca parecen ser la mayor intensidad de la voz, la mayor longitud vocálica y la mayor altura tonal.

De acuerdo con Rountree (1972b: 25-26), la asignación del acento dinámico está relacionada con la estructura silábica de la palabra y este recae sobre lo que ella denomina el pie fonológico de la raíz. Al parecer, este consiste típicamente de un pie disilábico trocaico (cf. Good 2004a: 16). Según esta autora, el acento dinámico se asigna a las raíces simples de acuerdo con las siguientes reglas:

a. El acento de intensidad recae sobre la primera sílaba larga de la palabra. Una sílaba larga consiste en un diptongo o en una vocal doble, v.gr. / kiíki / => [ 'kií ki ] arroyo, / bakaá / => [ ba'kaá ] hombre blanco. ${ }^{7}$

b. Si la palabra no tiene una sílaba larga, entonces el acento recae en la penúltima sílaba del pie fonológico de la raíz (el pie disilábico trocaico) ${ }^{8}$, v.gr. / náki / => [ 'náki ] golpear, / síkí/si / => [ 'síkísi ] seis, / kalu/wá / => [ 'kaluwá ] lagartija. ${ }^{9}$

c. Si se trata de una palabra bisilábica que contiene el patrón tonal $\mathrm{BH}$, entonces el acento de intensidad recae libremente o bien sobre la penúltima sílaba o bien sobre la última sílaba, v. gr. / bebé / => [ 'bebé be'bé ] beber. ${ }^{10}$

Aunque a primera vista la asignación del acento dinámico parece ser independiente del lugar que ocupa el acento tonal, Good (2004a, 2004b, 2006) sostiene que existe una correlación entre el acento dinámico y el acento tonal (como se ha dicho, expresado fonéticamente por un tono alto).

Good (2004a y 2004b) presenta las siguientes correlaciones entre tonos y acento dinámico en palabras polisilábicas compuestas de sílabas del tipo CV (es decir, de sílabas que no son largas):

\section{Palabras bisilábicas:}

$\begin{array}{lll}\text { Tonos } A B: & \text { 'náki } & \text { golpear } \\ \text { Tonos } B A: & \text { 'foló } & \text { flor }\end{array}$

\section{Palabras trisilábicas:}

Tonos $A A B$ :

'sákása sala

Tonos $B A B$ :

$$
\text { si'kífi }
$$

escribir

Tonos BBA:

'mokisá

aplastar

\section{Palabras tetrasilábicas:}

Tonos BAAB:

Tonos BBAB:

Tonos BBBA:

$\begin{array}{ll}\text { mi'nísíti } & \text { ministro } \\ \text { 'afokáti } & \text { abogado } \\ \text { a'lukutú } & \text { tipo de fruta }\end{array}$


Es evidente que Good no comparte la descripción que Rountree establece en la regla (c) descrita arriba, en cuanto a la asignación del acento dinámico en las palabras bisilábicas con el patrón tonal BA (cf. Good 2004a, nota 11). Además, Good (2004a: 17, algoritmo 8) logra establecer una correlación entre el lugar del acento tonal y el acento dinámico, basado precisamente en la división de las palabras trisilábicas y tetrasilábicas en pies disilábicos trocaicos, los cuales se forman, siempre que sea posible, a partir de la primera sílaba con tono alto que se halla más a la izquierda en la palabra. En estas palabras, el acento dinámico primario recae en la primera sílaba del primer pie disilábico (un pie disilábico trocaico), corresponda esta al lugar del acento tonal (fonéticamente tono alto) o no. Así, las palabras anteriores presentarían los siguientes esquemas de correlación (cf. Good 2004b: 11 y 2004a: 17).

\section{Palabras trisilábicas:}

\begin{tabular}{|c|c|c|}
\hline Tonos $A A B:$ & 'sákása & ('CúCv́) (CV) \\
\hline Tonos BAB: & si'kífi & (CV) ('CúCV) \\
\hline Tonos BBA: & 'mokisá & $(' \mathrm{CVCV})(\mathrm{C} v)$ \\
\hline
\end{tabular}

\section{Palabras tetrasilábicas:}

$\begin{array}{lll}\text { Tonos } B A A B: & \text { mi'nísíti } & (\mathrm{CV})(\text { 'C v́Cv́) }(\mathrm{CV}) \\ \text { Tonos } B B A B: & \text { 'afokáti } & \text { ('CVCV) (Cv́CV) } \\ \text { Tonos } B B B A: & \text { a'lukutú } & (\mathrm{CV})(\text { 'CVCV) (Cv́) }\end{array}$

De cualquier modo, tanto Rountree como Good concuerdan en que el acento dinámico no tiene carácter contrastivo en saramaca.

De manera facultativa, las sílabas inacentuadas pueden sufrir una elisión vocálica, especialmente en los contextos sVC y CVs, como en las palabras /sikífi/ => [si'kífi 'skífi] escribir y /bókúsu/ => [ 'bókúsu 'bóksu] caja. Esta elisión parece ser consecuencia de los llamados efectos negativos del acento (Good 2004a: 15).

Por otro lado, también de manera facultativa, las vocales de las sílabas acentuadas pueden alargarse por énfasis, como en la palabra /sákása/ => [ 'sákása 'sá:kása] sala (Good 2004a: 15).

Además, también existe una regla de alargamiento de las vocales que es independiente de la asignación del acento tonal o dinámico. Esta regla determina el alargamiento de una vocal en posición final de enunciado, siempre y cuando esté precedida de otra vocal, como en la palabra /muzéc/ => [mu'zéc:] mujer (Good 2004a: 17, nota 12).

Según Good (2004a: 21-22) las sílabas con tonos bajos subyacentes no están sujetas a las propiedades del acento dinámico descritas anteriormente.

\subsection{El palenquero}

La mayoría de las referencias a la prosodia de esta lengua en el siglo XX son muy breves y tienen una base impresionista (cf. v.gr. Montes 1962: 450; Bickerton y Escalante 1970; Friedemann \& Patiño 1983: 110). Sin embargo, todas las descripciones de estos autores coinciden en señalar diferencias sustanciales en la prosodia entre esta lengua y el español, que es la lengua de superestrato de esta variedad.

Los autores de las descripciones más extensas y confiables sobre los suprasegmentales de esta lengua, Moñino (2001) y sobre todo Hualde \& Schwegler (2008), sostienen que el palenquero debe 
ser considerado una lengua de acento tonal y no de acento dinámico, como el español. Esto se debe, sobre todo, a que la sílaba acentuada se realiza por medio de un tono de nivel alto y la inacentuada por un tono de nivel bajo. Estos autores, al igual que Bickerton y Escalante (1970), señalan que, en general, la altura tonal es un rasgo más relevante que la duración para determinar el lugar del acento en la palabra, aunque estos investigadores y otros (Montes 1962: 450 y Patiño 1983: 110) sostienen que la duración es, en algunos casos, también un correlato del acento.

Desde el punto de vista fonológico, Bickerton \& Escalante (1970) y Moñino (2001) afirman que los patrones de distribución tonal tienen carácter contrastivo en esta lengua.

\subsubsection{El acento tonal}

Desde el punto de vista fonético, Hualde \& Schwegler (2008) demuestran que el correlato fundamental del acento es la altura tonal. En general, las vocales de las sílabas acentuadas presentan consistentemente un tono alto y las vocales de las inacentuadas un tono bajo (cf. figura 3, p. 10).

Además, según Moñino (2001) y Hualde \& Schwegler (2008), la penúltima sílaba acentuada combina los correlatos fonéticos de altura (tono alto) y duración (sílaba larga). El autor de este trabajo ofrece, en el apartado siguiente, una interpretación alternativa de esta consideración, que también, como se ha dicho, ha sido reportada por Montes (1962) y Friedemann \& Patiño (1983).

Desde el punto de vista fonológico, como es típico en el caso de las lenguas de acento tonal, en palenquero existen restricciones en la aparición de los tonos en palabras polisilábicas, ya que no aparecen palabras simples que presenten dos tonos altos ni solamente tonos bajos. Se pueden reconocer los siguientes patrones de distribución tonal en palabras primitivas polisilábicas, ${ }^{11}$ los cuales tienen carácter contrastivo (cf. especialmente Moñino 2001):

\section{Palabras bisilábicas}

$\begin{array}{lll}\text { Tonos } A B: & \text { bóngo } & \text { especie de árbol } \\ & \text { láto } & \text { rato } \\ & \text { móna } & \text { abeja } \\ \text { Tonos } B A: & \text { bongó } & \text { tambor } \\ & \text { lató } & \text { ratón } \\ & \text { moná } & \text { hijo }\end{array}$

Palabras trisilábicas:

$\begin{array}{lll}\text { Tonos } B A B: & \begin{array}{l}\text { kusína } \\ \text { naríse } \\ \text { eféma }\end{array} & \begin{array}{l}\text { cocina } \\ \text { nariz } \\ \text { enferma }\end{array} \\ \text { Tonos } B B A: & \begin{array}{l}\text { kusiná } \\ \text { matiká } \\ \text { efemá }\end{array} & \begin{array}{l}\text { cocinar } \\ \text { enfermar }\end{array} \\ & \text { hígaro } & \text { hígado } \\ \text { páharo } & \text { pájaro } \\ \text { lámpara } & \text { lámpara }\end{array}$


Palabras tetrasilábicas:

$\begin{array}{lll}\text { Tonos BBAB: } & \begin{array}{l}\text { karabéla } \\ \text { amaríjo }\end{array} & \begin{array}{l}\text { calavera } \\ \text { amarillo }\end{array} \\ & \text { maranguángo } & \text { bebedizo } \\ \text { konos BBBA: } & \text { kamahaná } & \text { hombre importante } \\ & \text { titiritiá } & \text { especie de arbol } \\ & \text { tiritar }\end{array}$

Además, en palabras monosilábicas, los tonos tienen carácter distintivo. Sin embargo, como suele suceder en las lenguas de acento tonal, los tonos altos aparecen solamente en palabras de contenido (especialmente nombres, verbos y pronombres), mientras que los tonos bajos ocurren en palabras de índole gramatical (conjunciones y preposiciones). ${ }^{12}$

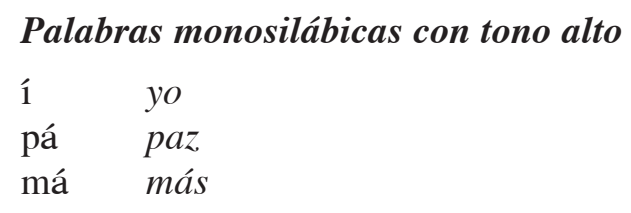

\section{Palabras monosilábicas con tono bajo}

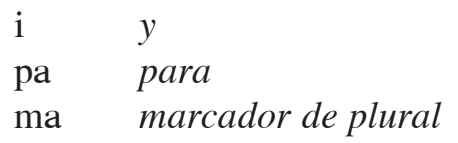

Por otro lado, Hualde y Schwegler (2008: 20 y ss.) también reportan la existencia de una regla de descenso final (downstep) en palenquero. Según esta regla, el tono alto (A) de la última sílaba acentuada de un enunciado se realiza como un tono fonéticamente medio (M), después de un tono bajo (sílaba inacentuada) en oraciones declarativas (1) o también después de un tono alto (sílaba acentuada) en oraciones exclamativas (2). ${ }^{13}$

$$
\begin{array}{lll}
\text { pa yebá pa bendé. } & \Rightarrow & {[\text { pa yebá pa bēndē }]} \\
/ \mathrm{B}+\mathrm{BA}+\mathrm{B}+\mathrm{BA} / & \Rightarrow & {[\mathrm{B}+\mathrm{BA}+\mathrm{B}+\mathrm{MM}]} \\
\text {.. para llevar a vender. } & &
\end{array}
$$

$$
\begin{array}{lll}
\text { nú dehá mí té nú! } & \Rightarrow & \text { [nú dehá mí té nū] } \\
\text { /A }+\mathrm{BA}+\mathrm{A}+\mathrm{A}+\mathrm{A} / & \Rightarrow & {[\mathrm{A}+\mathrm{BA}+\mathrm{A}+\mathrm{A}+\mathrm{M}]} \\
\text { ¡No me dejés (aquí)! } & &
\end{array}
$$

\subsubsection{El acento dinámico}

Como se ha dicho, diversos autores han reportado la existencia de un alargamiento de ciertas sílabas. Todos los autores han considerado esta mayor duración silábica un correlato del acento (tonal) en esta lengua. ${ }^{14}$

\footnotetext{
[...] quizá no sea muy aventurado atribuir a una influencia semejante [de 'posibles restos africanos'] el peculiarísimo tonillo palenquero, una de cuyas más salientes características es la notoria elevación del tono y el alargamiento cuantitativo de la sílaba acentuada. (Montes 1962: 450)
} 
[...][alargamiento] más exactamente de la última sílaba acentuada. (Friedemann \& Patiño 1983: 110)

Des mesures de différences de hauteur, d'intensité et de durée montrent que les contrastes entre syllabes ne sont pas dus à un accent d'intensité, mais exclusivement à la hauteur tonale (haute, basse, descendante) sur les toutes les syllabes, excepté pour les antépénultimièmes 'accentueés' qui combinent la hauteur et la durée. (Moñino 2001: 2)

Accented phrase-'penultimate' syllabes are extraordinarily lenghtened under the 'long nuclear fall' contour. (Hualde \& Schwegler 2008: 25)

Todos los autores correlacionan el alargamiento silábico con la posición paroxítona del acento. Sostienen que la mayor duración de la sílaba está relacionada con el emplazamiento del acento en la penúltima sílaba de la frase. Es decir, afirman que la duración es otro correlato fonético del acento en palenquero, junto con la altura.

Sin embargo, realmente resulta extraño que, en esta lengua, el acento tonal se realice fonéticamente como tono alto en todas las posiciones, pero como tono alto y mayor duración silábica solo en la posición paroxítona final de enunciado.

Una posible explicación alternativa para esta aparente excepcionalidad es considerar que la mayor duración silábica es el correlato fonético de la presencia de un acento dinámico en esta lengua.

No es extraño que las lenguas que presentan tonos léxicos o un acento tonal tengan también acento dinámico. Precisamente, tal es el caso tanto del papiamento como del saramaca, descritos anteriormente. ${ }^{15}$

En el presente estudio, se afirma entonces que el palenquero tiene, por un lado, un acento tonal, que tiene carácter contrastivo, cuyo correlato fonético es únicamente la mayor altura tonal. Y se propone que, por otro lado, esta lengua también exhibe un acento dinámico predecible de carácter no contrastivo. En palenquero, este acento dinámico recae, como muestran Hualde \& Schwegler (2008), en la posición paroxítona final de frase, especialmente cuando se trata de oraciones declarativas (que son los enunciados no marcados en las lenguas del mundo).

De acuerdo con lo que señalan todos los autores, el correlato fonético principal de este acento dinámico predecible sería una mayor duración de la sílaba. Hay que recordar que, en las lenguas del mundo, los correlatos fonéticos del acento suelen ser principalmente la intensidad de la sílaba (stress), la altura tonal de las vocales (height) y la duración vocálica (length). La relevancia de cada uno de estos correlatos para la manifestación del acento es variable en las lenguas particulares.

Hualde \& Schwegler (2008: 29 Tabla 1) señalan que, en una muestra escogida de frases con palabras de sílabas abiertas, el promedio de la duración de las vocales acentuadas en la posición paroxítona final de frase es de $188.0 \mathrm{~ms}$. En estas mismas frases, la duración promedio de las vocales en posición pretónica (posición proparoxítona) es de $106.8 \mathrm{~ms}$. y de las vocales en posición postónica (posición oxítona) es de $99.9 \mathrm{~ms}$. Los autores afirman que vowels in accented syllables bearing a nuclear long fall tend to have roughly twice the duration of vowels in immediately precceding and following unaccented syllables (Hualde \& Schwegler 2008: 29).

Esto demuestra, sin duda alguna, la certeza de las apreciaciones hechas por todos los autores citados de una mayor duración de las penúltimas sílabas acentuadas en la frase final de enunciado. Además, de manera muy significativa, esta mayor duración de la sílaba ocurre no solamente cuando la penúltima sílaba está acentuada, como señalan repetidamente todos los autores. Un análisis de los mismos datos ofrecidos por Hualde \& Schwegler 
(2008: 13, 17, 19, 21, 22 y passim) indica que también ocurre una mayor duración silábica, especialmente vocálica, cuando se trata de una sílaba inacentuada que se halla en posición paroxítona, en una frase final de un enunciado declarativo.

La mediciones de la longitud de las dos últimas sílabas de una palabra bisilábica, la penúltima con tono bajo y la última con tono alto, realizadas por Hualde \& Schwegler (2008: 19, 20,22) en tres frases declarativas, muestran que la penúltima sílaba con tono bajo siempre tiene una duración mayor que la última sílaba con tono alto. ${ }^{16}$

Penúltima sílaba con tono bajo

Última sílaba con tono alto

1. / mamá / $\quad \mathrm{ma}=277 \mathrm{~ms}$. má $=267 \mathrm{~ms}$.

2. / moná / $\quad \mathrm{mo}=286 \mathrm{~ms}$.

ná $=209 \mathrm{~ms}$.

3. / bendé / ben $=255 \mathrm{~ms}$. dé $=185 \mathrm{~ms}$.

\section{Promedio}

$272.6 \mathrm{~ms}$.

220.3 ms.

Ciertamente, la diferencia en la longitud de las vocales de las penúltimas sílabas respecto de aquellas de las últimas sílabas es mayor cuando estas portan un tono alto (188.0 / $99.9=89 \mathrm{~ms}$. $)$ que cuando llevan un tono bajo (272.6 / $220.3=53 \mathrm{~ms}$.).

De cualquier forma, es innegable que las penúltimas sílabas siempre son más largas que las últimas sílabas en estas condiciones, independientemente de que porten un tono alto o un tono bajo.

Por otro lado, de manera interesante, Hualde \& Schwegler (2008) muestran que, en frases exclamativas, las sílabas finales con tono alto son bastante más largas (v. gr. 568 ms.) que las penúltimas sílabas (v.gr. 196 ms.), aunque estas también porten un tono alto.

En resumen, con base en los datos aportados por Hualde \& Schwegler (2008), propongo que existe en palenquero un acento dinámico, que tiene un carácter no contrastivo. Este acento recae automáticamente en la penúltima sílaba de las frases cuando se trata de enunciados declarativos. Este acento predecible es independiente del acento tonal contrastivo que también existe en esta lengua y cuyo correlato fonético es particularmente la mayor altura tonal.

\section{Los suprasegmentales del protopidgin afroportugués americano}

\section{1. ¿Lengua tonal, de acento tonal o de acento dinámico?}

El portugués, que es la lengua base del vocabulario de este protopidgin, es conocida como una lengua de acento dinámico. En esta lengua, el correlato fonético primordial del acento es la mayor intensidad de la sílaba acentuada. La sílaba acentuada de la última palabra del grupo fónico (o frase fonológica) presenta una intensidad mayor que las demás sílabas acentuadas del enunciado (cf. Azevedo 2005: 51 y ss.).

El acento tiene carácter contrastivo en esta lengua, ya que se asigna a las palabras léxicamente. Sin embargo, el patrón de asignación del acento en palabras polisilábicas más común o no marcado es el paroxítono: el acento recae sobre la penúltima sílaba. También, en palabras polisilábicas, se asigna un acento secundario no contrastivo cada dos sílabas a partir de la sílaba acentuada, v.gr. amanhã [ , ame'jũ ] mañana, superlativo [ su,perla'tivu ] superlativo, superestructura [,super,estruk'ture ] superestructura (Faria 2003: 8-9)

Las variaciones en la altura tonal (pitch) están relacionadas con la entonación afirmativa, interrogativa e imperativa. Tradicionalmente, se reconocen tres tonos de nivel o niveles de altura: 
bajo (1), medio (2) y alto (3). Además, aparecen dos tonos de registro o tonemas que ocurren solo al final del grupo fónico: uno ascendente y uno descendente. Así, en cláusulas afirmativas, por ejemplo, la primera sílaba acentuada de la cláusula lleva un tono medio, la última sílaba acentuada presenta un tono bajo y un tonema descendente $\left(\mathrm{E}^{2} \mathrm{la}\right.$ vem $^{2}$ amanhã $^{1} \searrow$ Ella viene mañana). En cláusulas interrogativas directas, la primera sílaba porta un tono medio, la última lleva un tono alto y un tonema ascendente (E² ja já2 chegou ${ }^{3}$ ? ‘ ¿Ella ya llegó?) (Azevedo 2005: 53-54).

Por otro lado, el vocabulario de lenguas africanas en saramaca proviene fundamentalmente de lenguas de la familia niger-congo, del grupo bantoide, especialmente del kikongo, y del grupo gbe, como el fon y el ewe (cf. Good 2009b). En el caso del papiamento, el vocabulario derivado de lenguas africanas es muy reducido. Sin embargo, los pocos términos reconocidos provienen principalmente del kikongo y del fon (Maurer 1998a: 183-84). En palenquero, la mayor parte de los rubros de lenguas africanas provienen del kikongo (Schwegler 2002, 2006; Patiño 2002). ${ }^{17}$

Ham (1999), Good (2003), Kramer (2005, 2007) han mostrado que diversas reglas de asimilación tonal que presenta el saramaca pueden ser consideradas transferencias de operaciones de asimilación tonal que provienen muy seguramente del fon y del kikongo. ${ }^{18} \mathrm{De}$ acuerdo con los datos demográficos (Arends 1995) y por los paralelos gramaticales que se han descubierto (McWorther 2005; Kramer 2006), es muy probable que el fon sea la lengua primaria de sustrato del saramaca y de otras lenguas de Surinam. Al igual que el saramaca, esta lengua presenta dos tonos fonológicos (alto y bajo) (Lefevre \& Brousseau 2002) ${ }^{19}$ y, como se ha dicho, reglas de asimilación tonal semejantes a las que aparecen en saramaca, aunque no iguales. Por otro lado, el kikongo, que es otra de las lenguas de sustrato fundamental del saramaca, presenta también un sistema dos tonos subyacentes (alto y bajo) (Samba 1989). Las correspondencias en la asignación de los tonos entre el kikongo y el saramaca en el vocabulario compartido son mayoritarias (cf. Daeleman 1972, tabla 1).

De acuerdo con lo descrito en los apartados anteriores, el protopidgin afroportugués americano debería ser considerado más una lengua acentual que tonal, ya que el vocabulario que presenta tonos subyacentes de origen fon y kikongo no puede ser reconstruido en esta protolengua. De hecho, el único rubro encontrado de un idioma africano que dos lenguas comparten es la palabra correspondiente a maní:

Saramaca pindá

Papiamento ' 'pínda < kikongo mpinda, yombe pínda ${ }^{20}$

Como se observa, el saramaca y el papiamento difieren en la asignación de los tonos. Este es un indicio de que estos rubros entraron en estas lenguas por vías distintas a las del pidgin afroportugués americano. Por otro lado, es relevante que este rubro del saramaca sea idéntico al que aparece en djuka, sranan y en otros criollos de base inglesa, como el inglés criollo de Limón (lengua criolla de base inglesa de Costa Rica), incluso en la asignación de los tonos (cf. inglés criollo de Limón pindá manî). Esto significaría una vía de ingreso diferente de estas palabras en saramaca y en papiamento, aunque, en última instancia, ambos rubros tengan un origen bantú en común. ${ }^{21}$

Por otro lado, dado que el saramaca, el papiamento y el palenquero son lenguas con restricciones en la aparición de tonos en palabras polisilábicas en el vocabulario compartido, lo cual es típico de las lenguas de acento tonal, es muy probable que originalmente el pidgin afroportugués utilizado por los esclavos africanos haya sido una lengua de acento tonal. Es decir, aunque el portugués, que es la base de este pidgin afroportugués utilizado en América 
entre mediados del siglo XVII y principios del siglo XVIII, haya sido una lengua de acento dinámico, la población de esclavos africanos expresaría la mayor culminación prosódica propia de las sílabas acentuadas no por medio de una mayor longitud vocálica o una mayor intensidad espiratoria, sino fundamentalmente con una mayor altura tonal.

Así, por lo general, la sílaba acentuada del portugués habría sido interpretada como una vocal con tono alto y las sílabas inacentuadas como una vocal con tono bajo por parte de los hablantes de este pidgin afroportugués. Por eso, como se verá más adelante, los rubros monosilábicos que presentan un tono alto o un tono bajo subyacente que pueden ser reconstruidos en la protolengua corresponden a monosílabos acentuados o inacentuados respectivamente en portugués.

La unidad portadora de tono en esta protolengua parece haber sido la mora. Esto se puede afirmar porque las vocales altas que forman parte de los protodiptongos *ai y *au (cf. Portilla 2007: 192) se realizan fonéticamente como segmentos vocálicos [i, u] en saramaca (Rountree 1973: 25), los cuales portan un tono bajo. Además, en esta lengua cada tono se asigna a cada una de las moras de una vocal doble o larga de manera independiente.

Por otro lado, esto no sucede en papiamento, en donde las vocales altas de los protodiptongos *ai y *au se realizan como paravocales [j, w] (Maurer 1998a: 148). ${ }^{22}$ En palenquero, el protodiptongo *ai se realiza como [ ae ] en dos cognados. En estos casos, la vocal media porta también un tono bajo. ${ }^{23}$

Para facilitar la comparación entre las variedades y debido a que el lugar que ocupan los tonos en cada vocal de los protodiptongos es predecible, estos serán presentados solamente con un tono alto sobre la vocal baja.

\subsection{Los tonos}

Se pueden reconstruir dos tonos de nivel con carácter contrastivo en el protopidgin afroportugués americano: uno alto (A) (' ) y otro bajo (B) (sin marcar).

\subsubsection{Tonos en palabras monosilábicas}

\section{Saramaca Papiamento Palenquero}

a. $\mathrm{A}$

ké

dá

mái

pái

tá

té

(dé)

Saramaca

b. B

(fu)

$\mathrm{ku}$

na

ma

mi
A

'ké

('duná)

'mái

'pay'25

'tá

'té

'tín

Papiamento

B

di

$\mathrm{ku}$

na

ma

mi
A

(kelé)

dá, ndá

máe

páe

tá

(áta, áhta)

tén

Palenquero

B

ri

$\mathrm{ku}$

(en)

(péro)

(i) 28
*A

*ké

*dá

*mái

*pái

*tá

*té

*tén querer

dar

madre ${ }^{24}$

padre $e^{26}$

aspecto progresivo ${ }^{27}$

hasta

tener
*B

*di

*ku

*na

*ma

*mi de

con, $y$

en

pero

yo (no enfático) 
Desde el punto de vista diacrónico, en los monosílabos, el prototono alto corresponde a una sílaba acentuada en portugués cuando estos rubros provienen de un sustantivo (*mái < port. mae), un verbo (*ké < port. quer; *dá < port. dar; *tá < port. está; *tén < port. tem) o un adverbio (*té < port. até). ${ }^{29}$

Por otro lado, el prototono bajo corresponde a una sílaba inacentuada en portugués cuando se trata de palabras de índole gramatical, las cuales normalmente carecen de acento en las lenguas acentuales, como preposiciones (*di < port. de; ${ }^{*} \mathrm{ku}<$ port. com; ${ }^{*}$ na $<$ port. na), conjunciones $(*$ ma $<$ port. mas) y pronombres clíticos no enfáticos $(*$ mi < port. mim).

De manera interesante, tanto en saramaca como en papiamento los artículos definidos son palabras gramaticales monosilábicas que presentan un tono alto. Esto se debe a que provienen de demostrativos acentuados: ing. this > sar. dí; esp./port este > pap. é.

\subsubsection{Tonos en palabras bisilábicas}

\section{Saramaca Papiamento Palenquero}

\begin{tabular}{|c|c|c|c|c|}
\hline $\mathrm{AB}$ & $\mathrm{AB}$ & $\mathrm{AB}$ & $* \mathrm{AB}$ & \\
\hline bít $\int u$ & 'bít $\mathrm{i}$ & (ngusáso) & *bítfu & gusano $^{30}$ \\
\hline fuúta & 'frúta & flúta ${ }^{31}$ & *frúta & fruta \\
\hline húpan & 'húna & $(-)$ & *úna & uña, garra \\
\hline lábu & 'rábu, & lábo & *rábu & rabo \\
\hline lánza & 'lánsa & $(-)$ & *lánsa & lanza \\
\hline líba & 'ríba & síba & *ríba & sobre, encima de \\
\hline límbo, & 'límpi & (límpio) & *límpu & limpio \\
\hline línzo & 'lízu & $(-)$ & *lízu & liso \\
\hline lío & 'ríu & (río) & *ríu & río \\
\hline múndu & 'múndu & múndo & *múndo & mundo ${ }^{32}$ \\
\hline sábi & 'sábi, 'sá & (sabé) & *sábi & saber \\
\hline sínta & 'sínta & sínta & *sínta & cinta, cinto \\
\hline
\end{tabular}

$\begin{array}{lllll}\text { b. } & \text { BA } & \text { BA } & \text { BA } & \text { *BA } \\ \text { bebé } & \text { 'bebé } & \text { bebé } & \text { *bebé } & \text { beber } \\ \text { dendá }{ }^{33} & \text { 'drentá } & \text { lendrá } & \text { *dentrá } & \text { entrar } \\ \text { duumí } & \text { 'drumí } & \text { (n)drumí }{ }^{4} & \text { *drumí } & \text { dormir } \\ \text { feegá } & \text { 'fregá } & \text { fregá } & \text { *fregá } & \text { fregar } \\ \text { giintá } & \text { 'gritá } & \text { ngritá } & \text { *gritá } & \text { gritar }{ }^{35} \\ \text { jabí36 } & \text { 'habrí } & \text { abrí } & \text { *abrí } & \text { abrir } \\ \text { kabá } & \text { 'kabá } & \text { kabá } & \text { *kabá } & \text { acabar } \\ \text { kaí } & \text { 'kaí } & \text { kaí } & \text { *kaí } & \text { caer } \\ \text { kandá } & \text { 'kantá } & \text { kandá } & \text { *kantá } & \text { cantar } \\ \text { kulá } & \text { 'kurá } & \text { kulá } & \text { *kurá } & \text { curar } \\ \text { kulé } & \text { 'kuri } & \text { kulé } & \text { *kuré } & \text { correr } \\ \text { palí, paí } & \text { 'barí } & \text { parí } & \text { *parí } & \text { parir }{ }^{37} \\ \text { pidí } & \text { 'pidí } & \text { pirí } & \text { *pidí } & \text { pedi }\end{array}$


En el protopidgin afroportugués americano, el esquema de distribución tonal parece estar determinado por la clase gramatical a la que pertenecen los lexemas. El esquema AB corresponde fundamentalmente a nombres (sustantivos y adjetivos) ${ }^{38}$ y el esquema BA es asignado especialmente a verbos.

El verbo reconstruido *sábi saber constituye una excepción a esta generalización. Esta inconsistencia se puede explicar, por un lado, por el hecho de que este verbo proviene etimológicamente de la forma del verbo en presente de tercera persona singular del portugués (sabe), la cual es paroxítona, y no del infinitivo como sucede en la mayoría de los casos. Como se ha dicho antes, en las tres lenguas, existe una pequeña cantidad de verbos que provienen de la forma del presente de tercera persona singular del portugués: *ké < port. quer; *tá < port. está; *tén < port. tem. Es probable que estos verbos sean resabios de un estado anterior de esta misma protolengua.

Por otro lado, la palabra sabir existía ya en la llamada lingua franca, conocida también precisamente como sabir, un pidgin de base romance, utilizado en el mediterráneo desde el siglo XI hasta el siglo XIX y seguramente de dominio de los primeros marineros portugueses de ultramar. ${ }^{39}$ Como es probable que esta palabra formara parte del vocabulario marinero europeo, hay formas relacionadas con este étimo en otras lenguas criollas que no son de base portuguesa, como en el inglés criollo de Limón (sáibi). ${ }^{40}$

Por otra parte, la preposición o adverbio *ríba sobre, encima proviene de un sustantivo, riba, el cual significaba orilla, ribera. Por lo tanto, es natural que presente el esquema de distribución tonal AB propio de la clase gramatical de los nombres.

\subsubsection{Tonos en palabras trisilábicas}

\section{Saramaca \\ Papiamento Palenquero}

\begin{tabular}{|c|c|c|c|c|}
\hline BAB & BAB & BAB & $* \mathrm{BAB}$ & \\
\hline bíka ${ }^{41}$ & ba'ríka & baríka & *baríka & estómago, barriga \\
\hline bulíki & bu'ríku & (búlo) & *buríku & burro, borrico \\
\hline didía $^{42}$ & di'día & $(-)$ & *didía & día \\
\hline gujába & gu'jába & (guajába) & *gujába & guayaba \\
\hline katíbo & ka'tíbu & $(-)$ & *katíbu & esclavo $^{43}$ \\
\hline makáku & ma'káku & (móno) & *makáku & mono \\
\hline $\mathrm{BBA}$ & BBA & BBA & $* \mathrm{BBA}$ & \\
\hline bakajáu & baki'jóu & $(-)$ & *bakajáu & bacalao \\
\hline gumbitá & gumbi'tá & $(-)$ & *gumbitá & vomitar \\
\hline papiá & papi'á & papiá 44 & *papiá & hablar, charlar \\
\hline papakái & papa'gái & (papagádzo) & *papagái 45 & papagayo \\
\hline sakwí & saku'dí & $(-)$ & *sakudí & sacudir \\
\hline
\end{tabular}

En primer lugar, llama la atención de que no es posible reconstruir rubros con el esquema de distribución tonal ABB. Como se mencionó anteriormente, las palabras esdrújulas o proparoxítonas en papiamento provienen claramente del español y son una minoría. Probablemente, lo mismo podría afirmarse del palenquero. En saramaca tampoco existen palabras con este esquema de asignación tonal. 
Por otro lado, todas las palabras con el esquema de distribución tonal BAB que se pueden reconstruir son sustantivos. Esto es reflejo de la tendencia paroxítona de los nombres en portugués.

Además, los términos con el esquema de distribución tonal BBA son de dos tipos: verbos (*gumbitá, *papiá, *sakudí) y sustantivos que contienen un diptongo (*bakajáu, *papagái). En el caso de los verbos, de nuevo, esta situación refleja la realización oxítona de los infinitivos en portugués. Los sustantivos que contienen un diptongo siempre portan el tono alto sobre la vocal baja del diptongo, por ser esta una sílaba pesada. ${ }^{46}$

\subsubsection{Tonos en las vocales intrusas del saramaca}

Portilla (2007) describe la intrusión de vocales en saramaca, las cuales no existían en la protolengua, por procesos de paragoge y epéntesis. ${ }^{47}$ Por esta razón, se observan inconsistencias en el número de sílabas de ciertas palabras entre el saramaca y las otras dos lenguas comparadas.

\subsubsection{Tonos bajos en vocales paragógicas}

\section{Saramaca Papiamento Palenquero}

\begin{tabular}{|c|c|c|c|c|}
\hline $\begin{array}{l}\mathrm{AB} \\
\text { búnu }\end{array}$ & $\begin{array}{l}\text { A } \\
\text { 'bón }\end{array}$ & $\begin{array}{l}(-) \\
\text { (búeno) }\end{array}$ & $\begin{array}{l}\text { *A } \\
\text { *bón }\end{array}$ & bueno \\
\hline $\begin{array}{l}\text { BAB } \\
\text { alísi }\end{array}$ & $\begin{array}{l}\text { BA } \\
\text { 'arós }\end{array}$ & $\begin{array}{l}\text { BA } \\
\text { aló }\end{array}$ & $\begin{array}{l}* \mathrm{BA} \\
* \text { *arós }\end{array}$ & arroz \\
\hline
\end{tabular}

La inclusión de la vocal / u / en el rubro *bón bueno ocurre cuando la protoconsonante / n / está precedida por una vocal simple no anterior. Esta regla se aplica también a términos de origen inglés y holandés. ${ }^{48}$ Riemer (1779) presenta las formas 'bunn' y 'bunnu' y describe una regla de aparición de cada una de ellas (cf. Portilla 2007: 194). Esta vocal siempre porta un tono bajo.

En el rubro *arós arroz se añade la vocal paragógica /i/después de la protoconsonante /s/ cuando esta se halla en posición final de sílaba. ${ }^{49}$ Esta regla se aplica también a otros rubros tanto de origen portugués como inglés y holandés. ${ }^{50}$ En esta posición, la vocal lleva un tono bajo.

2.2.4.2. Tonos altos en vocales epentéticas

\section{Saramaca Papiamento Palenquero}

$\begin{array}{llllll}\text { a. } & \text { AAB } & \text { AB } & (-) & \text { *AB } & \\ \text { kákísa } & \text { 'káska } & (-) & \text { *káska } & \text { corteza } \\ \text { b. } & \begin{array}{l}\text { BAAB } \\ \text { olóísi }\end{array} & \begin{array}{l}\text { BAB } \\ \text { o'ló } j \mathrm{i}\end{array} & (-) & \text { *BAB } & \\ & & (-) & \text { *olófi } & \text { reloj }\end{array}$

En el caso del rubro *káska corteza, la inclusión de la vocal / i / aparece, como se ha dicho, cuando la protoconsonante / s / se halla en posición preconsonántica.

Riemer (1779) recoge las formas 'kassika' y 'kakkisa'. Evidentemente, la forma saramaca moderna ha sufrido un proceso de metátesis de la forma más antigua. La derivación 
de la forma actual de este rubro a partir de la protoforma es la siguiente: *káska > kásíka (1779) > kákísa (1779) > kákísa.

En la forma *oló ji reloj, ${ }^{52}$ la aparición de la vocal paragógica / i / está propiciada por la consonante alveopalatal siguiente. ${ }^{53}$ La derivación de este rubro en saramaca desde el portugués es la siguiente: relogio $\sim$ rologio $^{54} /$ relózio $\sim$ rolózio / > *olózio > *olózii > *olózi > *oló $\int i$ > olóí $\int i$ > olóísi.

En ambos rubros, la vocal paragógica presenta un tono alto. Esto se debe a que, en saramaca, toda vocal que originalmente presente un tono bajo y que esté precedida de otra vocal con tono alto en posición proparoxítona toma un tono alto. Esta regla se aplica en todas las vocales paragógicas en estas condiciones y afecta a otros rubros de origen inglés y holandés.

$\begin{array}{ll}\text { bókúsu } & <\text { ing. box 'caja' } \\ \text { síkísi } & <\text { ing. six 'seis' } \\ \text { minísíti } & <\text { hol. minister 'ministro' } \\ \text { wólúku } & <\text { hol. wolk 'nube' }\end{array}$

Esta regla también afecta a las vocales con tono bajo en palabras compuestas cuando van seguidas de una vocal con tono alto en el primer elemento del compuesto.

$\begin{array}{lll}\text { sitónúmiíi piedra } & <\text { sitónu + míi } & \text { < ing. stone 'piedra' + port. menino 'pequeño' } 55 \\ \text { míndífési frente } & <\text { míndi + fési } & \text { < ing. middle 'medio' + ing. face 'cara' } \\ \text { máúnmáun (estar) } & <\text { máun + máun } & <\text { port. mau 'malo' + port. mau 'malo' } \\ \text { grave } & & \\ \text { sákúsáku en sacos } & <\text { sáku + sáku } & \text { < port. saco 'saco' + port. saco 'saco' }\end{array}$

2.2.4.3. Tonos bajos en vocales epentéticas

\section{Saramaca Papiamento Palenquero}

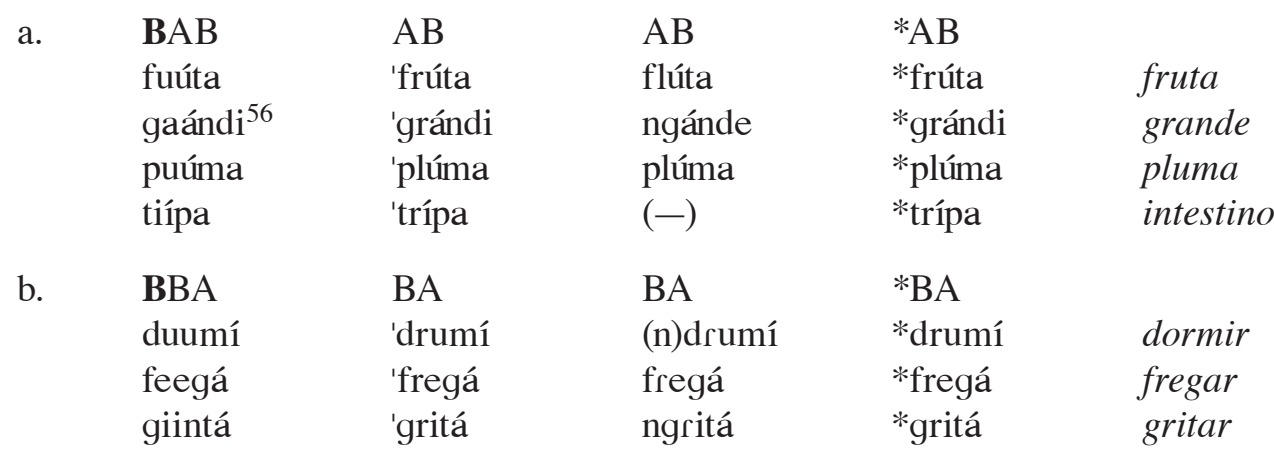

En saramaca, aparece una serie de vocales epentéticas que no existían en la protolengua reconstruida. La regla de epéntesis consiste en introducir una vocal idéntica a la que constituye el núcleo de una sílaba formada por una consonante obstruyente y una consonante líquida / *1, *r /. Es probable que la vocal epentética aparezca como una compensación prosódica por la pérdida de las consonantes líquidas, la cual ocurrió en saramaca probablemente en el siglo XIX (cf. Portilla 2007: 194-195). 


$\begin{array}{llllll}\text { c. } & \text { BBAB } & \text { BA } & (-) & \text { *BA } & \\ \text { sipajólu } & \text { 'spajó } & (-) & \text { *spajól } & \text { español } \\ \text { d. } & \begin{array}{l}\text { BAB } \\ \text { sugúu }\end{array} & \begin{array}{l}\text { BA } \\ \text { 'sukú, skur }\end{array} & \begin{array}{l}(-) \\ \text { (asuka, ekúro) }\end{array} & \text { *AB } & \\ & \text { skúru } & \text { oscuro }\end{array}$

Como se ha dicho, en saramaca, y a veces en papiamento, aparece una vocal epentética / i, u / después de la consonante / s / cuando esta se encuentra en posición preconsonántica. La vocal epentética porta un tono bajo siempre y cuando no esté precedida de una sílaba con una vocal con tono alto (cf. 2.4.2.a). En saramaca, otros ejemplos de la aplicación de esta regla en rubros de origen portugués, inglés y holandés son los siguientes:

$\begin{array}{ll}\text { sikáda } & \text { < port. escada 'escalera' } \\ \text { sipéi } & <\text { port. espelho 'espejo' } \\ \text { sitónu } & \text { < ing. stone 'roca' } \\ \text { sumúku } & \text { < ing. smoke 'humo' } \\ \text { sipónsu } & \text { < hol. spons 'esponja' } \\ \text { sukúfu } & <\text { hol. scroef 'desatornillador' }\end{array}$

\subsubsection{Tonos bajos subyacentes en saramaca}

\section{Saramaca Papiamento Palenquero}

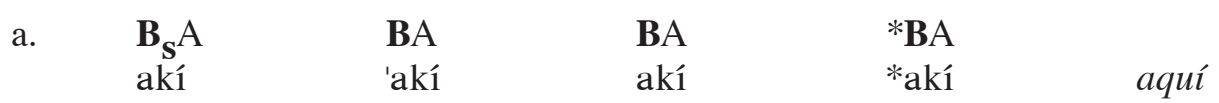

Solamente se puede reconstruir una palabra en la que los tonos bajos subyacentes del saramaca corresponden a tonos bajos (ausencia de acento tonal) en papiamento y palenquero.

En saramaca, en palabras polisilábicas, los tonos bajos subyacentes aparecen fundamentalmente en rubros provenientes de lenguas africanas (Good 2009b). Como se ha dicho, no es posible reconstruir ninguna palabra de estos orígenes en la protolengua.

Sin embargo, existen dos palabras de claro origen portugués que portan tonos bajos subyacentes en saramaca. Estas palabras son las siguientes (Rountree 1972; Good 2006):

\section{Saramaca}

àkí <*akí < port. aquí

àlá < *alá < port. alá 57

Evidentemente, los tonos bajos subyacentes corresponden a la sílaba inacentuada del portugués. Sin embargo, como se ha visto, en la mayoría de los casos, la sílaba inacentuada del portugués corresponde a la ausencia de acento tonal expresada por tonos bajos no subyacentes. Más adelante se plantea una hipótesis que relaciona la existencia de los tonos bajos subyacentes con la ausencia de un acento secundario en la protolengua en palabras bisilábicas con el patrón tonal BA (cf. 2.3.1).

Por otro lado, en papiamento es común que los adverbios bisilábicos de origen ibérico presenten el esquema de distribución tonal BA:

\section{Papiamento}

$$
\begin{aligned}
& \text { 'akí < *akí < port. aquí } \\
& \text { 'awé < ?port./esp. hoy }
\end{aligned}
$$


'awó < ?port./esp. agoralahora

'també < port. también

'trobé < port. outra vez

\subsubsection{Reglas sandhi y de descenso final}

Tanto el saramaca como el papiamento presentan reglas sandhi o de asimilación tonal. Algunas de reglas de realización tonal en saramaca han sido atribuidas a influencia de sustrato de lenguas africanas (cf. Ham 1999; Good 2003; Kramer 2005, 2007). Lamentablemente, una comparación minuciosa de tales reglas escapa a las posibilidades de la presente investigación. Sin embargo, la comparación superficial entre las reglas de asimilación tonal descritas aquí para el papiamento y para el saramaca muestra cierta similitud entre ellas. En ambas lenguas, una de estas reglas predice que los tonos bajos que corresponden a una sílaba inacentuada se convierten en tonos bajos después de un tono bajo.

Papiamento

$$
\begin{array}{lll}
\text { é sáku á skér } & \Rightarrow & \text { [é sákú á skér ] } \\
/ \mathrm{A}+\mathbf{A B}+\mathrm{A}+\mathrm{A} / & \Rightarrow & \mathrm{A}+\mathbf{A A}+\mathrm{A}+\mathrm{A}
\end{array}
$$

La bolsa se rompió

\section{Saramaca}

$$
\begin{aligned}
& \text { dí sukuáti súti } \\
& / \mathrm{A}+\mathrm{B}^{0} \mathrm{~B}^{0} \mathrm{AB}^{0}+\mathrm{AB}^{0} / \\
& \text { El chocolate está bueno }
\end{aligned}
$$$$
\Rightarrow \quad[\text { dí súkúátí súti }]
$$$$
\Rightarrow \quad[\mathrm{A}+\mathbf{A} \mathbf{A} \mathrm{AA}+\mathrm{AB}]
$$

Sin embargo, las condiciones en las que se aplican estas reglas de asimilación tonal son, al parecer, diferentes en cada una de las lenguas comparadas. Por ello, no es posible establecer con certeza si en el pidgin afroportugués americano existiría ya algún tipo de regla sandhi de esta naturaleza. ${ }^{58}$

Por otro lado, tanto el saramaca como el palenquero presentan reglas de descenso final (downstep). En ambas lenguas, en ciertos casos el tono alto (A) de las vocales en posición final de enunciado se convierte en tono medio (M) después de un tono bajo.

\section{Saramaca}

$$
\begin{array}{lll}
\text { dí káìmà kulé alá } & \Rightarrow & {[\text { dí káima kulé alā }]} \\
/ \mathrm{A}+\mathrm{AB}^{\mathrm{s}} \mathrm{B}^{\mathrm{s}}+\mathrm{B}^{0} \mathrm{~A}+\mathbf{B}^{\mathrm{s}} \mathbf{A} / & \Rightarrow & {[\mathrm{A}+\mathrm{ABB}+\mathrm{BA}+\mathbf{B M}]} \\
\text { El lagarto está corriendo allá. } &
\end{array}
$$

\section{Palenquero}

$$
\begin{array}{lll}
\text { pa yebá pa bendé. } & \Rightarrow & {[\text { pa yebá pa bēndē }]} \\
/ \mathrm{B}+\mathrm{BA}+\mathrm{B}+\mathrm{BA} / & \Rightarrow & {[\mathrm{B}+\mathrm{BA}+\mathbf{B}+\mathbf{M M}]} \\
\text {.. para llevar } \text { a vender } . & &
\end{array}
$$

Sin embargo, también en este caso, las condiciones de realización de este descenso final son, en general, distintas en cada lengua. De hecho, el descenso final es simplemente común en las lenguas de tipo tonal. 


\subsection{El acento}

Como se ha dicho, el acento en papiamento y en palenquero es contrastivo, mientras que en saramaca es predecible. También, se ha mencionado que los tonos altos de la protolengua (así como en cada una de las variedades comparadas) corresponden bastante exactamente al lugar que ocupa la sílaba acentuada en portugués. También, en general, las sílabas inacentuadas del portugués se relacionan muy exactamente con los tonos bajos en la protolengua. Por ello, no es posible reconstruir un acento primario con carácter distintivo independiente del tono alto en el protopidgin afroportugués americano. Sin embargo, sí es factible establecer un posible origen del acento dinámico en cada una de las variedades comparadas.

\subsubsection{Orígenes del acento dinámico en saramaca}

Aunque el acento no es distintivo en saramaca a diferencia del portugués, esta lengua criolla presenta una fuerte tendencia a colocar el acento dinámico en la penúltima sílaba cuando la palabra tiene una estructura silábica $(\mathrm{CV})^{\prime} \mathrm{CVCV}$, al igual que sucede todavía actualmente en portugués. Hay que recordar que, en palabras con una estructura silábica del tipo CV, el saramaca tiene un pie disilábico trocaico como dominio de la asignación del acento dinámico. En esta lengua, se asigna un acento dinámico a la primera sílaba de este pie disilábico.

De manera muy significativa, como se ha descrito anteriormente, el portugués asigna un acento secundario cada dos sílabas de derecha a izquierda a partir de la sílaba acentuada. Es decir, el portugués actualmente asigna un acento secundario a la primera sílaba de cada pie disilábico. Esto quiere decir que perfectamente existe una correspondencia entre el emplazamiento del acento secundario en portugués y el lugar que ocupa el acento en dinámico en las palabras polisilábicas con la estructura silábica del tipo CV en saramaca. Esto lleva a suponer con bastante certeza que el pidgin afroportugués americano asignaba un acento secundario de la misma manera que lo hace actualmente el portugués moderno. La correspondencia entre el acento dinámico del saramaca y el acento secundario del portugués se puede ilustrar con el siguiente ejemplo:

\begin{tabular}{|c|c|c|}
\hline Saramaca & $\begin{array}{l}\text { Portugués } \\
\text { ama'jã }\end{array}$ & $\begin{array}{l}\text { Protopidgin afroportugué } \\
\text { *amaná }\end{array}$ \\
\hline anán] & [ ,ama'jã] & [*amaná] \\
\hline
\end{tabular}

Por otra parte, según lo descrito por Rountree (1972), en palabras bisilábicas con el patrón de asignación tonal BA, el lugar del acento dinámico varía colocándose o bien sobre la penúltima sílaba, de acuerdo con la regla mencionada anteriormente, o bien sobre la última sílaba. Incluso Good (2004a, nota 11) sostiene que las palabras con este patrón de asignación tonal presentan el acento dinámico en la última sílaba (cf. supra 1.2.2).

Esta anomalía puede ser explicada como los resabios de otra regla general del portugués, que es una tendencia universal de las lenguas acentuales: colocar el acento dinámico sobre la sílaba pesada de la palabra (Kiparsky 2008: 50). ${ }^{59}$ En saramaca, la mayor parte de las palabras bisilábicas de origen portugués con el esquema de asignación tonal BA corresponde a rubros que en portugués portaban el acento en la última sílaba, la cual generalmente era pesada.

Es probable que el pidgin afroportugués americano presentara en estas palabras bisilábicas un acento primario sobre la última sílaba, como resabio de su naturaleza pesada original en portugués, el cual fue interpretado como un tono alto por los hablantes de lenguas 
africanas tonales, y un acento secundario sobre la primera sílaba del pie disilábico, como sucede todavía facultativamente en saramaca, por la tendencia del portugués a acentuar la penúltima sílaba.

\begin{tabular}{|c|c|c|c|}
\hline Saramaca & Portugués & Protopidgin afro & ués \\
\hline bebé & be'ber & *bebé & \\
\hline [ 'bebé be'bé] & [be'ber] & [*,bebé] & beber \\
\hline mujéc 60 & mu'Ker & *mujér & \\
\hline [mu'jéc] ${ }^{61}$ & [mu'Ker] & {$\left[{ }^{*}\right.$, mujér $]$} & mulher \\
\hline
\end{tabular}

Por otro lado, las palabras bisilábicas que en saramaca presentan el patrón de asignación tonal BA que provienen de rubros portugueses acentuados en la última sílaba, pero que no es pesada, son precisamente los casos de àkí < *akí < port. aquí y àlá < port. alá. ${ }^{62}$

Como se ha dicho, de manera extraña, estas palabras portan un tono bajo subyacente en vez de presentar un tono bajo que corresponda simplemente a la ausencia de acento tonal, como sucede en casi la totalidad de los rubros de origen portugués en esta lengua. Hay que recordar que las sílabas con un tono bajo subyacente no permiten la aparición de un acento dinámico sobre ellas (Good 2004a: 21-22).

Esto podría ser un indicio de que, en el pidgin afroportugués americano, las palabras bisilábicas aquí y allá no hubieran presentado nunca un acento secundario en la penúltima sílaba como sí habría sucedido presumiblemente en otros rubros con acentuación oxítona cuya última sílaba hubiera sido pesada originalmente. Así, pues, precisamente la ausencia de un acento secundario en estos rubros habría sido interpretada por los hablantes de lenguas africanas de la comunidad saramacana como la presencia de un tono bajo subyacente. La realización fonética de estos rubros en el pidgin afroportugués americano en comparación con el verbo beber muestra que la ausencia de un acento secundario a nivel fonético en la protolengua habría determinado la aparición de tonos bajos subyacentes en estas palabras. Como se ha dicho, la presencia de un acento secundario en las palabras bisilábicas dependería de que los rubros contuvieran una sílaba pesada en portugués.

Rubros con la última sílaba liviana en portugués

Port. aquí a'ki [a'ki] > protopidgin *akí [*akí] > sar. àkí [àkí]

Port. alá a'la [a'la] > protopidgin *alá [*alá] > sar. àlá [àlá]

Rubros con la última sílaba pesada en portugués

Port. beber be'ber [be'ber] > protopidgin *bebé [*'bebé] > sar. bebé [ 'bebé be'bé]

Port. curar ku'rar [ku'rar] > protopidgin *kurá [* kurá] > sar. kulá [ 'kulá ku'lá]

Si en la protolengua las palabras aquí y allá hubieran presentado un acento dinámico secundario sobre la primera sílaba, este podría haber sido tomado como la prominencia máxima de la palabra, por llevar la vocal / a / en la penúltima sílaba y por constituir un pie disilábico trocaico. En estas palabras, confluirían dos tendencias universales de las lenguas acentuales que favorecen la colocación del acento principal sobre la penúltima sílaba: constituir un pie trocaico y contener en esta sílaba la vocal más sonante o fuerte en la escala de sonoridad. ${ }^{63}$

En el proceso de cambio lingüístico, la prominencia acústica intrínseca de las vocales fuertes suele interpretarse como un acento dinámico (Kiparsky 2008: 50). Por ello, es natural que se evitara colocar un acento secundario en la primera sílaba en palabras con 
tal estructura fonológica, pues de lo contrario sería difícil determinar cuál sería la vocal con mayor prominencia. Este no sería el caso de las palabras con una sílaba pesada en la posición oxítona, ya que esta estructura silábica es preferiblemente acentuable por naturaleza en las lenguas del mundo.

Además, es significativo también que, en palenquero, el rubro lá < *alá allá carezca de la vocal con tono bajo de la protolengua. Esto podría ser otro indicio de que esta vocal presentaba en la protolengua un carácter débil o completamente átono.

\subsubsection{Orígenes del acento en papiamento}

A diferencia del saramaca, en papiamento el acento dinámico tiene carácter contrastivo. Sin embargo, los datos apuntan a que este acento tomó una función contrastiva principalmente a causa del vocabulario de origen español introducido posteriormente en papiamento.

Como se nota a continuación, los contrastes fonológicos en parejas de palabras debidos a la colocación del acento corresponden a rubros que provienen de lenguas distintas. Estas parejas que contrastan por el lugar del acento son de origen portugués y español. Sin embargo, no es posible encontrar pares de palabras solamente de origen portugués.

\section{Palabras paroxítonas}

$\begin{array}{ll}\text { 'kasá casar } & <\text { port./esp. casar } \\ \text { 'matá matar } & <\text { port. matar } \\ \text { 'pará parar } & <\text { port./esp. parar } \\ \text { 'piská pesca } & <\text { port. pescar }\end{array}$

\section{Palabras oxítonas}

$$
\begin{array}{ll}
\text { ka'sá esposo/a } & <\text { esp. casado } \\
\text { ma'tá matado } & <\text { esp. matado } \\
\text { pa'rá parado } & <\text { esp. parado } \\
\text { pis'ká pez } & <\text { esp. pescado }
\end{array}
$$

Por ello, no es posible reconstruir palabras que presenten diferencias acentuales contrastivas en la protolengua. Más bien, al igual que sucede en saramaca, los tonos altos en papiamento corresponden muy exactamente al lugar que ocupa la sílaba acentuada en portugués.

En primer lugar, las palabras bisilábicas que presentan un contraste tonal $\mathrm{AB}$ (especialmente nombres) frente a BA (especialmente verbos) en esta lengua portan siempre el acento dinámico primario en la penúltima sílaba.

$\begin{array}{ll}\text { Esp. pesca }> & \text { 'píska pesca } \\ \text { Port. pescar }> & \text { 'piská pescar } \\ \text { Esp. } \text { mata }> & \text { 'máta planta } \\ \text { Port. } \text { matar }> & \text { 'matá matar } \\ \text { Esp. pájaro }> & \text { 'pára pájaro } \\ \text { Port. parar }> & \text { 'pará parar }\end{array}$

En el caso de los verbos bisilábicos, el lugar que ocupa el acento primario en papiamento corresponde presumiblemente a un acento secundario de la protolengua, tal como sucede también con el acento dinámico en el saramaca y en palenquero.

$\begin{array}{llll}\text { Saramaca } & \text { Papiamento } & \text { Palenquero } & \text { Protopidgin afroportugués } \\ \text { bebé } & \text { 'bebé } & \text { bebé } & \text { *bebé } \\ \text { ['bebé } \sim \text { be'bé] } & \text { ['bebé] } & \text { ['be:bé] } & \text { [*,bebé] }\end{array}$


Por otra parte, todas las palabras bisilábicas que en papiamento llevan el acento en la última sílaba y tienen el patrón tonal BA provienen indudablemente del español. Algunos de estos rubros son nombres o participios terminados en vocal que se oponen contrastivamente a los verbos con el patrón tonal BA y el acento en la penúltima sílaba.

$\begin{array}{ll}\text { Esp. pescado }> & \text { pis'ká pez } \\ \text { Esp. matado }> & \text { ma'tá matado } \\ \text { Esp. parado }> & \text { pa'rá parado } \\ \text { Esp. mujer }> & \text { mu'hé mujer } \\ \text { Esp. dolor }> & \text { do'ló dolor }\end{array}$

Luego, las palabras trisilábicas y tetrasilábicas que portan el acento en la penúltima sílaba también provienen del español. Es decir, tampoco es posible reconstruir palabras con este patrón de distribución acentual en la protolengua.

$\begin{array}{ll}\text { Esp. último }> & \text { 'último último } \\ \text { Esp. península }> & \text { pe'nínsula península } \\ \text { Esp. científico }> & \text { sien'tífiko científico } \\ \text { Esp. sílaba }> & \text { 'sílaba sílaba }\end{array}$

Por otro lado, los nombres polisilábicos terminados en consonante que llevan el acento o bien en la última sílaba o bien en la penúltima sílaba provienen del español, del holandés o de otras lenguas:

$\begin{array}{ll}\text { Esp. } \text { corazón }> & \text { kura'són corazón } \\ \text { Esp. } \text { virtud }> & \text { bir'tút virtud } \\ \text { Esp. } \text { animal }> & \text { ani'mál animal } \\ \text { Esp. hombre }> & \text { 'hómber hombre } \\ \text { Esp. joven }> & \text { 'hóben joven } \\ \text { Hol. apel }> & \text { 'ápel manzana }\end{array}$

Además, existe en papiamento una serie verbos trisilábicos y tetrasilábicos terminados en vocal que portan el acento en la última sílaba. Muchas de estas palabras provienen más probablemente del español.

$\begin{array}{ll}\text { Esp. equivocar }> & \text { ekibo'ká equivocar } \\ \text { Esp. abandonar }> & \text { bando'ná abandonar } \\ \text { Esp. detener }> & \text { dete'né detener }\end{array}$

Sin embargo, otros de estos verbos con esta estructura silábica se derivan del portugués e incluso puede ser reconstruidos en la protolengua. En el nivel fonético, estas palabras presentan en papiamento un acento secundario en la primera sílaba. Como se ha dicho, este se corresponde con el lugar que ocupa el acento dinámico en saramaca.

$\begin{array}{llll}\text { Saramaca } & \text { Papiamento } & \text { Protopidgin afroportugués } \\ \text { gumbitá } & \text { gumbi'tá } & \text { *gumbitá } & \\ \text { ['gumbitá] } & \text { [,gumbi'tá] } & \text { [*gumbitá] } & \text { vomitar } \\ \text { sakwí } & \text { saku'dí } & \text { *sakudí }^{*} & \\ \text { [ 'sakwí] } & \text { [,saku'dí] } & \text { [*'sakudí] } & \text { sacudir }\end{array}$


El emplazamiento del acento secundario sobre la primera sílaba de un pie trocaico a partir de la sílaba acentuada en papiamento y también en el protopidgin afroportugués americano tiene su origen claramente en el portugués (cf. supra 2.1).

Actualmente, este patrón de colocación del acento secundario se aplica a todas las palabras del papiamento aunque no se trate necesariamente de verbos. Estos rubros pueden ser de origen portugués o español.

$\begin{array}{lll}\text { Esp. aguacero }> & \text { awa'séru [,awa'séru] } & \text { aguacero } \\ \text { Esp. anteayer }> & \text { anta'jéra [,anta'jera] } & \text { anteayer } \\ \text { Port. bacalhao }> & \text { baki'jóu [,baka'jau] } & \text { bacalao } \\ \text { Port. pagagai }> & \text { papa'gái [,papa'gai] } & \text { papagayo }\end{array}$

\subsubsection{Orígenes del acento dinámico en palenquero}

Como se ha visto en las formas reconstruidas, el acento tonal del palenquero (expresado por un tono alto) corresponde bastante exactamente con el lugar que ocupa el acento primario del portugués, al igual que sucede en saramaca y en papiamento.

El acento dinámico del palenquero (expresado por una mayor duración silábica) recae siempre en la penúltima sílaba de una frase final de un enunciado declarativo.

Como se ha dicho, esta tendencia a la colocación del acento dinámico en la posición paroxítona puede ser atribuida al portugués.

Por su parte, Huade \& Schwegler (2008: 38) sugieren que la presencia de una mayor duración de la penúltima sílaba de las frases finales de enunciado en palenquero, que es el principal correlato fonético del acento dinámico postulado aquí, puede deberse a una influencia de sustrato de las lenguas bantúes, ya que este fenómeno parece ser común en las lenguas de este grupo lingüístico (cf. también Maddieson 2003: 40).

Se ha postulado la existencia de un acento secundario en el pidgin afroportugués en esta posición silábica. La correspondencia entre el acento dinámico de palenquero y un presumible acento secundario del pidgin afroportugués americano se puede ilustrar a continuación.

\begin{tabular}{|c|c|c|c|c|}
\hline Saramaca & Papiamento & Palenquero & \multicolumn{2}{|c|}{ Protopidgin afroportugués } \\
\hline $\begin{array}{l}\text { bebé } \\
\text { ['bebé be'bé] }\end{array}$ & $\begin{array}{l}\text { 'bebé } \\
\text { [ 'bebé] }\end{array}$ & $\begin{array}{l}\text { bebé } \\
\text { ['be:bé] }\end{array}$ & $\begin{array}{l}\text { *bebé } \\
{[* \text {,bebé }]}\end{array}$ & beber \\
\hline $\begin{array}{l}\text { kandá } \\
\text { [ 'kandá kan'dá] }\end{array}$ & $\begin{array}{l}\text { 'kantá } \\
\text { [ 'kantá] }\end{array}$ & $\begin{array}{l}\text { kandá } \\
\text { [ 'ka:ndá] }\end{array}$ & $\begin{array}{l}\text { *kantá } \\
\text { [*,kantá] }\end{array}$ & cantar \\
\hline $\begin{array}{l}\text { líba } \\
\text { [ 'líba] }\end{array}$ & $\begin{array}{l}\text { 'ríba } \\
\text { [ 'ríba] }\end{array}$ & $\begin{array}{l}\text { síba } \\
\text { [ 'rísba] }\end{array}$ & $\begin{array}{l}\text { *ríba } \\
{\left[{ }^{*}, \text { ríba }\right]}\end{array}$ & $\begin{array}{l}\text { sobre, } \\
\text { encima }\end{array}$ \\
\hline $\begin{array}{l}\text { baíka } \\
\text { [ba'íka] }\end{array}$ & $\begin{array}{l}\text { ba'ríka } \\
\text { [ba'ríka] }\end{array}$ & $\begin{array}{l}\text { baríka } \\
\text { [ba'ríkka] }\end{array}$ & $\begin{array}{l}\text { *baríka } \\
\text { [*ba,ríka] }\end{array}$ & estómago \\
\hline
\end{tabular}

En los ejemplos anteriores, se nota que solamente en los verbos existe una discrepancia en el lugar que ocupa el tono acento tonal (tono alto) y el acento dinámico en palenquero. Cuando se trata de sustantivos, aparece una confluencia entre el acento tonal y el acento dinámico en esta lengua. Este hecho ha sido precisamente el que ha llevado a la confusión de los autores a la hora de describir los correlatos fonéticos del acento tonal en esta lengua. 
Al igual que sucede en papiamento, las palabras trisilábicas con el patrón de distribución tonal ABB, provienen con toda seguridad del español.

$\begin{array}{lll}\text { Esp. hígado } & > & \text { hígaro hígado } \\ \text { Esp. pájaro } & > & \text { páharo pájaro } \\ \text { Esp. lámpara } & > & \text { lámpara lámpara }\end{array}$

Por ello, este patrón de distribución tonal no puede ser reconstruido en la protolengua. Lo mismo puede decirse de las palabras tetrasilábicas, las cuales son generalmente palabras compuestas y derivadas provenientes del español o de lenguas africanas. Algunas veces se trata de reduplicaciones.

$\begin{array}{lll}\text { Esp. pico }+ \text { gordo }> & \text { pikogóddo especie de pájaro } \\ \text { Esp. candil }+ \text { izar }> & & \text { kandilisá atizar } \\ \text { Kikongo moná }+r i+\text { Kongo } & > & \text { monikóngo congolés } 64 \\ \text { Kimbundu mbamba > } & & \text { imbá-imbá cosa sin importancia }{ }^{65}\end{array}$

\subsubsection{El acento secundario en el pidgin afroportugués americano}

De acuerdo con lo descrito en los tres apartados anteriores, se ha podido establecer una correspondencia entre la asignación del acento dinámico del saramaca, el acento dinámico primario o secundario del papiamento y el acento dinámico en palenquero para gran parte de los rubros que pueden reconstruirse en la protolengua. Este hecho permite postular un protoacento dinámico secundario en el pidgin portugués americano como el antecedente de esta correspondencia.

\begin{tabular}{|c|c|c|c|c|}
\hline \multirow{6}{*}{$\begin{array}{l}\text { Ac. dinámico } \\
\text { Saramaca } \\
\text { bebé } \\
\text { [ 'bebé } \sim \text { be'bé] } \\
\text { kulá } \\
\text { [ 'kulá } \sim \text { ku'lá] }\end{array}$} & Ac. primario & Ac. dinámico & \multicolumn{2}{|c|}{ *Acento secundario } \\
\hline & Papiamento & Palenquero & & \\
\hline & 'bebé & bebé & *bebé & beber \\
\hline & [ 'bebé] & [ 'be:bé] & [*,bebé $]$ & \\
\hline & 'kurá & kulá & *kurá & curar \\
\hline & [ 'kulá ] & [ 'kuilá] & [* ${ }^{*}$ kulá $]$ & \\
\hline
\end{tabular}

$\begin{array}{llll}\text { b. Ac. dinámico } & \text { Ac. secundario } & \text { *Acento secundario } & \\ \text { Saramaca } & \text { Papiamento } & & \text { vomitar } \\ \text { gumbitá } & \text { gumbi'tá } & \text { *gumbitá } & \\ \text { [ 'gumbitá] } & \text { [ gumbi'tá] } & \text { [*',gumbitá] } & \text { sacudir } \\ \text { sakwí } & \text { saku'dí } & \text { sakudí } & \\ \text { [ 'sakwí] } & {[\text {,saku'dí] }} & {\left[{ }^{*} \text { sakudí] }\right.}\end{array}$

El acento secundario en el pidgin portugués americano se asignaría a la primera sílaba de un pie disilábico a partir de la última sílaba con acento tonal.

En el caso de las palabras con los patrones tonales *AB y *BAB, habría una coincidencia entre el lugar que ocupa el acento tonal (tono alto) y el acento dinámico, como se ilustra a continuación. 


$\begin{array}{lllll}\text { c. Ac. dinámico } & \text { Ac. primario } & \text { Ac. dinámico } & \text { *Acento secundario } \\ \text { Saramaca } & \text { Papiamento } & \text { Palenquero } & & \\ \text { líba } & \text { 'ríba } & \text { ríba } & \text { *ríba } & \text { sobre, encima } \\ \text { [ líba] } & \text { ['ríba] } & \text { ['ríba] } & \text { [*ríba] } & \\ \text { baíka } & \text { ba'ríka } & \text { baríka } & \text { *baríka } & \text { estómago } \\ \text { [ba'íka] } & \text { [ba'ríka] } & \text { [ba'ríka] } & \text { [*ba,ríka] } & \end{array}$

Como se ha dicho, la presumible existencia de un acento secundario en la protolengua está respaldada por el hecho de que el portugués presenta, de la misma manera, un acento secundario en la penúltima sílaba de un pie disilábico de derecha a izquierda de manera recursiva a partir de la sílaba con acento primario.

\section{Conclusiones}

Las tres lenguas criollas comparadas presentan un sistema prosódico bastante semejante entre sí y ciertamente diferente de las lenguas de las que proviene su base léxica principal: el portugués, el inglés y el holandés para el saramaca; el portugués, el español y el holandés para el papiamento; y el español para el palenquero.

El papiamento presenta dos suprasegmentales: acento tonal, realizado fonéticamente como tono alto, y acento dinámico, expresado fonéticamente con una mayor intensidad y duración silábica. Ambos suprasegmentales tienen valor fonológico, ya que permiten contrastes de significado en esta lengua.

El saramaca muestra un sistema prosódico mixto. Una parte del léxico (especialmente el que proviene de las lenguas indoeuropeas) presenta acento tonal, expresado por medio de tono alto. Otra parte del vocabulario (especialmente el que se deriva de lenguas de la familia niger-congo) tiene tonos altos y tonos bajos subyacentes asignados léxicamente. Además, esta lengua presenta un acento dinámico, expresado fonéticamente como una mayor intensidad silábica y una mayor duración vocálica. Este acento dinámico es de carácter predecible y se asigna a la penúltima sílaba de un pie disilábico.

El palenquero también presenta dos suprasegmentales: un acento tonal, expresado por medio de un tono alto, y un acento dinámico, realizado fonéticamente con una mayor duración silábica. El acento tonal tiene carácter contrastivo en esta lengua. El acento dinámico es predecible y recae en la penúltima sílaba de la frase final de un enunciado declarativo.

De manera general, las formas cognadas de las tres lenguas comparadas permiten reconstruir tonos altos y tonos bajos que corresponden a sílabas con acento tonal y sílabas inacentuadas en el protopidgin afroportugués americano. Los patrones de distribución tonal que pueden ser reconstruidos en la protolengua son solamente los siguientes:

$\begin{array}{ll}\text { Palabras monosilábicas: } & * \mathrm{~A}, * \mathrm{~B} . \\ \text { Palabras bisilábicas: } & * \mathrm{AB}, * \mathrm{BA} . \\ \text { Palabras trisilábicas: } & * \mathrm{BAB}, * \mathrm{BBA} .\end{array}$

Las tres lenguas presentan, sin embargo, una mayor cantidad de patrones de distribución tonal y palabras con un mayor número de sílabas.

En el presente estudio, se propone que el pidgin afroportugués americano, que dio origen a las tres variedades comparadas, es una lengua de acento tonal, a diferencia del 
portugués, que es un idioma de acento dinámico. Se supone que los hablantes africanos habrían interpretado el acento dinámico del portugués como un tono alto, debido a que su sustrato lingüístico eran lenguas tonales, que son comunes en la familia niger-congo como el fon, el ewe, el kikongo y el kimbundu. Varios autores han señalado que estas lenguas habrían sido predominantes durante la conformación de los idiomas criollos comparados.

Por último, es posible reconstruir un acento dinámico en la protolengua. Este acento dinámico corresponde a un acento secundario que habría existido en el pidgin afroportugués americano independientemente del acento tonal primario. El acento dinámico recaería de forma automática y recursiva siguiendo un patrón disilábico trocaico a partir de la última sílaba con acento tonal. En las palabras bisilábicas, el acento recaería siempre sobre la penúltima sílaba, pues la palabra completa constituye en sí misma un pie disilábico trocaico.

\section{Palabras bisilábicas}

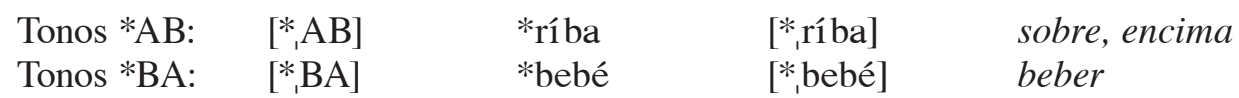

\section{Palabras trisilábicas}

Tonos *BAB: $\quad\left[* \mathrm{~B}_{1} \mathrm{AB}\right]$

Tonos *BBA: $\left[{ }^{*} \mathrm{BBA}\right]$

*baríka [*ba,ríka]

*gumbitá estómago, barriga

vomitar

En el presente estudio, se presume que es muy probable que el acento dinámico secundario de la protolengua tenga su origen en el portugués mismo, pues en esta lengua existe un patrón semejante de asignación de un acento secundario.

\section{Abreviaturas}

$\begin{array}{ll}\text { esp. } & \text { español } \\ \text { hol. } & \text { holandés } \\ \text { ing. } & \text { inglés } \\ \text { pap. } & \text { papiamento } \\ \text { port. } & \text { portugués } \\ \text { sar. } & \text { saramaca }\end{array}$

\section{Notas}

* Vaya mi agradecimiento para Armin Schwegler de la Universidad de California en Irvine por sus valiosos comentarios y atinadas observaciones al manuscrito preliminar de este artículo

1. El fon es citado en las fuentes también como fongbe, que significa lengua fon.

2. Es decir, en palabras que no son compuestas ni derivadas.

3. Las fuentes consultadas no indican si los tonos bajos especificados en palabras de origen africano corresponden a ausencia de acento o a tonos bajos subyacentes. Por ello, no es posible agregar otros ejemplos para el patrón tonal BBBA.

4. Good denomina a esta regla de asimilación regla de nivelación (plateauing). 
5. Rountree describe esta regla como a final voice drop.

6. Stressed syllables are louder, slightly longer, and their tones are slightly exaggerated (p. 309, nota 4)

7. Ejemplos tomados de Good (2004a: 20).

8. El pie se establece de izquierda a derecha y sus límites son señalados aquí con el símbolo ‘ /.

9. Los dos últimos ejemplos son tomados de Rountree (1972b: 22).

10. Ejemplo tomado de Rountree (1972b: 26). El original presenta este rubro con vocales flojas / bebé /. Aquí se ha preferido seguir la interpretación fonológica del SIL.

11. Se trata de palabras que no son compuestas ni derivadas. También se excluyen las palabras que son reduplicaciones, las cuales en algunos casos presentan dos tonos altos en la raíz reduplicada (cf. Moñino 2001).

12. Los ejemplos son tomados de Moñino (2001).

13. Los ejemplos son tomados de Hualde \& Schwegler (2008).

14. La negrita no existe obviamente en los originales.

15. Cf. Yip (2002: 97 y ss.) para una descripción de algunas relaciones entre el tono y el acento dinámico en diversas lenguas.

16. Cuadro basado en los datos of recidos por Hualde \& Schwegler (2008).

17. Las lenguas de los grupos bantoide y gbe son las que más han contribuido con vocabulario en los criollos atlánticos, incluso en aquellos que no son de base portuguesa (cf. Huttar 1985: 46).

18. Plag y Uffmann (2000) han mostrado también como la aplicación sistemática de una regla de paragoge en sranan puede tener su origen en el kikongo y en el fon.

19. La realización fonética de los tonos subyacentes es alto, bajo, ascendente, descendente y medio.

20. Las etimologías son sugeridas por Maurer 1998: 184 y Huttar 1985: 55 respectivamente.

21. Contrariamente a lo afirmado aquí para el protopidgin afroportugués americano, sí es posible reconstruir una cierta cantidad de términos de origen africano para un protocriollo inglés del Atlántico (cf. Portilla 1994) entre los que se incluyen, por ejemplo, los siguientes:

Igbo $u n u>*$ *ún ustedes $>$ sar. únu $\sim$ un $\sim \mathrm{u}$, IC de Limón únu.

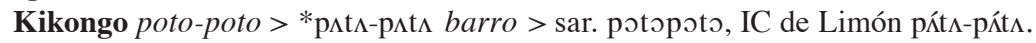

Wolof nyam > *nám comer > sar. ján, IC de Limón nám.

Kikongo taatá $>$ *taatá papá > sar. taatá, IC de Limón ta:tá.

22. En papiamento, por lo general, las vocales altas se realizan como paravocales en cualquier caso de agrupamiento con otra vocal. Esta tendencia a convertir cualquier agrupamiento vocálico en diptongo es característico de las variedades más conservadoras del español americano y un resabio del estado más antiguo del español americono, consecuencia de un proceso de koinización (cf. Quesada Pacheco 2000: 48). 
23. No se hallaron cognados para el protodiptongo *au.

24. El significado de este rubro en saramaca es suegra, nuera y en papiamento es mamá (como forma de tratamiento).

25. Este rubro aparece en uno de los documentos primitivos de papiamento que data de 1775 (Maurer 1998a: 203).

26. El significado de este rubro en saramaca es suegro, yerno y en palenquero es compadre, amigo.

27. El significado de este marcador en saramaca es de aspecto durativo, en papiamento de tiempo presente y en palenquero de progresivo.

28. Esta palabra proviene del español yo.

29. La palabra até funciona como un adverbio o una preposición en portugués.

30. Esta forma pervive en portugués en el lexema bicho-da-seda 'gusano de seda'.

31. Esta forma ha sido suministrada por Schwegler en comunicación personal.

32. En saramaca, esta palabra significa universo.

33. Riemer 1779 recoge la forma 'dindra'.

34. Schwegler (comunicación personal).

35. En saramaca, esta palabra significa gruñir, bramar; en papiamento, además de gritar, significa ladrar, aullar.

36. Riemer 1779 registra la forma 'jabri'.

37. Este rubro también significa dar fruto y poner (huevos) en estas lenguas.

38. Existen en saramaca excepciones a la asignación del esquema tonal $\mathrm{AB}$ en nombres de origen portugués, como avó abuelo, abuela < port. avô, avó y muzéc < *muzére < *muzér mujer < port. mulher (vid. infra).Por supuesto, se trata de una minoría de rubros que también en portugués llevan el acento en la última sílaba.

39. Por ejemplo, esta palabra aparece en A glossary of Lingua Franca 2005. https://pantherfile.uwm.edu/ corre/www/franca/edition3/index.html.

40. Esta forma es arcaica y actualmente obsolescente en esta lengua. Otro rubro de origen portugués que aparece en el criollo inglés de Costa Rica (y por supuesto en otros criollos ingleses del Atlántico) es la palabra pıkní niño < port. pequenino.

41. Riemer 1779 registra la forma 'barika'. 
42. Riemer 1779 recoge la forma 'dedia'. En esta lengua esta palabra significa también amanecer (daylight).

43. El significado de este rubro en saramaca es actualmente esclavitud.

44. En palenquero el significado de este rubro es decir disparates, hablar demasiado (Armin Schwegler, comunicación personal)

45. La forma reconstruida correspondiente al protopidgin afroportugués americano es más arcaica que la forma actual del portugués papagaio. Esta es idéntica a la forma original del occitano papagai, la cual dio origen a los rubros de las lenguas ibéricas (Corominas 1983).

46. Normalmente, una sílaba pesada es aquella que contiene una vocal larga (V:), un diptongo (VV) o una coda consonántica (VC).

47. Estos procesos podrían ser atribuidos a la influencia de sustrato fon y kikongo (Plag \& Uffmann 2000).

48. Por ejemplo, pánu < ing. pan 'sartén'; babúnu < ing. baboon 'babún'; buúu < hol. bloed 'sangre'.

49. El cambio inesperado $*_{0}>$ i se debe probablemente a una asimilación vocálica a la vocal paragógica. La derivación de este rubro a partir de la protoforma reconstruida es la siguiente: *arós > arósi > alósi >alísi (1779) > alísi.

50. Por ejemplo, adzóisi < port. adeus 'adiós'; pási < ing. path 'sendero'; tási < hol. tas 'bolsa'.

51. Riemer 1779 recoge las formas 'kakkisa' y 'kassika'. La derivación de la forma actual a partir de la protoforma es la siguiente: *káska > kásíka (1779) > kákísa (1779) > kákísa.

52. En las lenguas de la península ibérica, este término proviene directamente del catalán relotge, actualmente rellotge. Sin embargo, en esta lengua, también se registra una forma más antigua arolotge (1368) que conserva la vocal / o / etimológica latina < horologium (Corominas, 1983).

53. Otros rubros que presentan este fenómeno son adzóisi < port adeus 'adiós' (Riemer 1779 recoge la forma 'adjoshi') y sinéisi < chinês 'chino'.

54. El cambio o $>$ e constituye una disimilación que no es extraña en las lenguas iberorrománicas, como se nota en el caso del español formoso $>$ fermoso 'hermoso'.

55. El rubro sitónu significa roca en saramaca.

56. En saramaca esta palabra significa viejo.

57. En portugués estándar, la forma actual es lá. La forma más antigua alá pervive en ciertas variedades dialectales. Además, se debe señalar que el hecho de que en portugués moderno este rubro carezca de vocal átona podría ser un indicio de que esta vocal originalmente presentara realmente carácter débil o átono. Esto habría propiciado su desaparición en el mismo portugués moderno.

58. Un argumento en contra de tal pretensión es el hecho de que se encuentran reglas sandhi similares en otros criollos atlánticos que no están emparentados con estas lenguas, como es el caso del inglés criollo 
de Limón. Este criollo es una lengua de acento tonal que presenta también una regla de asimilación tonal semejante, la cual convierte facultativamente todos los tonos bajos en tonos altos después del primer tono alto (Portilla 1995).

59. Cf. nota 31 .

60. La derivación de esta palabra desde el portugués es la siguiente: port. mulher mu'Ker $>$ muzéri (1779) > mujére $>$ muzéle $>$ muzée $>$ muzée $>$ muzéc.

61. Hay que recordar en este rubro el acento dinámico recae sobre la última sílaba debido a una regla general obliga a la caída del acento sobre la sílaba larga de la palabra.

62. En portugués, este tipo de patrón acentual no es común en palabras patrimoniales. Otro de los pocos casos que pueden ser reconstruidos en la protolengua es el rubro avó < *avó < port. avô, avó 'abuelo, abuela'. Lamentablemente, las fuentes consultadas no indican con certeza si este rubro presenta un tono bajo subyacente en la primera vocal, como sería lo esperable.

63. Kiparsky (2008: 50) presenta la siguiente escala implicacional de sonoridad: $\mathrm{a}>\mathrm{e}, \mathrm{o}>\mathrm{i}, \mathrm{u}>$.

64. moná + ri + Kongo = hijo + de + Congo (Schwegler 1989: 21).

65. mbamba = concha o caracol que se usa como moneda de baja denominación (Del Castillo 1984: 37).

\section{Bibliografía}

Arends, Jacques. 1995. "Demographic factors in the formation of Sranan”. En: Arends (ed.), 233-285.

Arends, Jacques (ed.). 1995. The early stages of creolization. Amsterdam: Benjamins.

Arends, Jacques et al. (eds.). 1995. Pidgins and Creoles. An introduction. Amsterdam/ Filadelfia: Benjamins.

Azevedo, Milton. 2005. Portuguese: A linguistic introduction. Cambridge: Cambridge University Press.

Bakker, Peter et al. 1995. “Saramaccan”. En: Arends et al. (eds.), 165-178.

Bartens, Angela. 1995. Die iberoromanisch-basierten Kreolsprachen: Ansätze der linguistischen Beschreibung. Frankfurt/ Main: Peter Lang.

Bickerton, Derek \& Aquiles Escalante. 1970. "Palenquero: A Spanish based Creole of Northen Colombia". Lingua 24: 254-267.

Booij, Geert \& Jaap van Marle (eds.). 2003. Yearbook of Morphology 2002. Dordrecht: Kluwer. 
Corominas, Joan. 1983. Diccionario etimológico de la lengua castellana. Madrid: Gredos.

Daeleman, Jan. 1971. “Kongo words in Saramacca Tongo”. En: Hymes (ed.), 281-283.

Del Castillo, Nicolás. 1984. "El léxico negro-africano de San Basilio de Palenque”. Thesarurus. 39(1): 80-169.

Deumart, Ana \& Stephanie Durrleman (eds.). 2006. Structure and variation in language contact. Amsterdam/Filadelfia: Benjamins.

Faria, Arlo. 2003. “Applied phonetics: Text to speech”. http//:www.icsi.berkeley.edu/ arlo/ publications/faria_ling110_proj.pdf.

Friedemann, Nina \& Carlos Patiño. 1983. Lengua y sociedad en el Palenque de San Basilio. Bogotá: Instituto Caro y Cuervo.

Good, Jeff. 2003. "Morphosintactic tone raising in Saramaccan: The reanalysis of substrate phonology as tonal morphology". En: Booij \& Van Marle (eds.), 105-34. http://www. acsu.buffalo.edu/ jcgood/publications.html.

2004a. "Tone and accent in Saramaccan: Charting a deep split in the phonology of a language". Lingua. 114: 575-619.

2004b. "Split prosody and creole simplicity: The case of Saramaccan". Journal of Portuguese Linguistics. 3:11-30.

2006. "The phonetics of tone in Saramaccan". En: Deumart \& Durrleman (eds.), 9-28.

2009a. "A twice-mixed creole? Tracing the history of a prosodic split in the Saramaccan lexicon”. Studies in Language. 33: 459-498

2009b (Por aparecer). "Loanwords in Saramaccan". En Martin Haspelmath \& Uri Tadmoor (eds.) Loanwords in the world's languages: A comparative handbook. Mouton: De Gruyter. http://www.acsu.buffalo.edu/ jcgood/publications.html.

Good, Jeff (ed.). 2008. Linguistic universals and language change. Oxford: Oxford University Press.

Grimes, Joseph. (ed.). 1972. Languages of the Guianas. México: SIL.

Hasiver, Jay \& Kevin MacDonald (eds.). 2006. African re-genesis: Confronting social issues in the diaspora. Londres: University College London Press. 
Ham, William. 1999. “Tone sandhi in Saramaccan. A case of substrate transfer?". Journal of Pidgin and Creole Linguistics. 14: 45-92.

Hualde, José \& Armin Schwegler. 2008. "Intonation in Palenquero". Journal of Pidgin and Creole languages. 28(1): 1-31. http://netfiles.uiuc.edu/jihualde/www/.../HualdeSchwegler_Palenquero.pdf.

Huber, Magnus \& Viveka Vellupilai. 2007. Synchronic and diachronic perspectives on contact languages. Amsterdam/Filadelfia: Benjamins.

Huttar, George. 1972. “A comparative word list for Djuka”. En: Grimes (ed.), 12-21.

1975. "Sources of Ndjuka African vocabulary". New West Indian Guidel Nieuwe West-Indische Gids. 59: 45-71.

Hyman, Larry. 1978. “Tone and/or accent”. En: Napoli (ed.), 1-20.

Hymes, Dell (ed.). 1971. Pidginization and creolization of languages. Cambridge: Cambridge University Press.

Kiparsky, Paul. 2008. "Universal constrain change; change results in typological generalizations”. En: Good (ed.), 23-53.

Kramer, Johannes. 2004. Die Iberoromanische Kreolsprache Papiamento. Hamburgo: Helmut Buske.

Kramer, Marvin. 2005. "High tone spread in Saramaccan serial verb construction". Journal of Portuguese Linguistics. 4: 31-53.

2006. "The late transfer of serial verb constructions as stilistic variants in Saramaccan creole". En: Deumart \& Durrleman (eds.), 337-372.

2007. "Tone on quantifiers in Saramaccan as a transferred feature from Kikongo". En: Huber \& Vellupilai, 43-66.

Kouwenberg, Silvia \& Pieter Muysken. 1995. "Papiamento". Arends et al. (eds.), 205-18.

Lefevre, Claire \& Anne-Marie Brousseau. 2002. A grammar of Fongbe. Berlín/Nueva York: Gruyter.

Neumann-Holzschuh \& Edgar Schneider (eds.). 2000. Degrees of restructuring in creole languages. Amsterdam/Filadelfia: Benjamins.

Maddieson, Ian. 2003. "The sounds of the Bantu languages". En: Nurse \& Philippson, 15-41. 
Maurer, Philippe. 1998a. “El papiamento de Curazao”. En : Perl \& Schwegler (eds.), 139-218. 1998b. Les modifications temporelles et modales du verbe dans le Papiamento de Curaçao. Avec une antologie et un vocabulaire Papiamento-français. Hamburgo: Helmut Buske.

McWorther, John. 2005. Defining creole. Oxford: Oxford University Press.

Montes, José. 1962. "Sobre el habla de San Basilio de Palenque (Bolívar, Colombia)". Thesaurus. 17(2): 446- 450.

Moñino, Yves. 2001. "Le palenquero de Colombie: langue accentuelle ou langue t on a le?". Ponencia presentada en el Encuentro de la SPCL y la ACPBLE, Coimbra, Portugal.

Moñino, Yves \& Armin Schwegler (eds.). 2002. Palenque, Cartagena y Afro-Caribe. Historia y lengua. Tübingen: Niemeyer.

Papiamento-English/English-Papiamento lexicon. http://www.ats-group.net/dictionaries/ dictionary-english-papiamento.html.

Nurse, Derek \& Gérard Philippson. 2003. The Bantu languages. Nueva York: Routledge.

Patiño, Carlos. 2002. "Sobre origen [sic] y composición del criollo palenquero”. En: Moñino \& Schwegler (eds.), 21-49.

Plag, Ingo \& Christian Uffmann. 2000. "Phonological restructuring in creole: The development of paragoge in Sranan”. En: Neumann-Holzschuh \& Schneider (eds.), 309-336.

Perl, Mathias \& Armin Schwegler (eds.).1998. América negra. Panorámica actual de los estudios lingüísticos sobre variedades hispanas, portuguesas y criollas. Frankfurt/ Madrid: Vervuert/Iberoamericana.

Maduro, Antoine. 1987. Palenkero i papiamentu. Korsou.

Napoli, D.J. (ed.). 1978. Elements of tone, stress and intonation. Washington: Georgetown University Press.

Portilla, Mario. 1994. "Reconstrucción fonológica y del sistema de TMA del protocriollo inglés del Atlántico". Tesis doctoral: Universidad de Bielefeld.

1995. “Tono en el criollo inglés de Costa Rica”. Revista de Filología y Lingüística de la Universidad de Costa Rica. 21(1): 135-139. 
2007. "Reconstrucción fonológica del pidgin afroportugués americano: Las vocales". Revista de Filología y Lingüística de la Universidad de Costa Rica. 33(2): 179-203.

2008a. "Protopidgin afroportugués americano". Revista Internacional de Lingüística Iberoamericana (RILI). 6(1): 161-83.

2008b. "Reconstrucción fonológica del pidgin afroportugués americano: Las consonantes". Revista de Filología y Lingüística de la Universidad de Costa Rica. 34(1): 157-192.

Quesada Pacheco, Miguel Ángel. 2000. El español de América. Cartago: Editorial Tecnológica de Costa Rica.

Riemer, Johann Andreas. 1779. Wörterbuch zur Erlernung der Saramakka-Neger-Sprache. http://www.sil.org/americas/suriname/Riemer/National/RiemerNLDict.html.

Rivera-Castillo, Yolanda \& Lucy Pickering. 2004. "Phonetic correlates of stress and tone in a mixed system". Journal of Pidgin and Creole Languages. 19: 261-284.

Rountree, S. 1972a. "Saramaccan tone in relation to intonation and grammar". Lingua 29: 308-325.

1972b. "The phonological structure of stems in Saramaccan". En: Grimes (ed.), 22-27.

Samba, P. 1989. "The system of tone in kikongo". Tesis doctoral: Universidad de Lancaster.

Schwegler, Armin. 1989. "Notas etimológicas palenqueras: casiambre, túngananá, agüé, monicongo, manicongo y otras voces africanas y pseudoafricanas". Thesaurus 44(1): 1-28.

2002. "El vocabulario africano de Palenque (Colombia). Compendio alfabético de palabras (con etimologías)". En: Moñino \& Schwegler (eds.), 171-226.

2006. "Bantu elements in Palenque (Colombia): Anthropological, archeological, and Linguistic evidence". En: Hasiver \& MacDonald (eds.), 204-222.

2009. "Palenque(ro): The search of its African substrate". (ms.)

Taylor, Douglas. 1977. Languages of the West Indies. Baltimore/Londres: The Johns Hopkins University Press.

Voorhoeve, Jan. 1961. "Le ton et la grammaire dans le saramaccan". Word. 17: 143-163.

Yip, Moira. 2002. Tone. Cambridge: Cambridge University Press. 